\title{
Capítulo 3 \\ Ecuador, escenario dinámico, entre la continuidad y la transición. De la hegemonía del neoliberalismo a la construcción de una economía social y solidaria
}

\author{
Ana Castro Medina
}

\section{SciELO Books / SciELO Livros / SciELO Libros}

CASTRO MEDINA, A. Ecuador, escenario dinámico, entre la continuidad y la transición. De la hegemonía del neoliberalismo a la construcción de una economía social y solidaria. In: Economía popular y solidaria: ¿realidad o utopía?. Caracterización de las entidades de fomento [online]. Quito: Editorial Abya-Yala, 2018, pp. 89-167. ISBN: 978-9978-10-490-3.

https://doi.org/10.7476/9789978104903.0004.

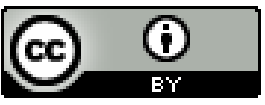

All the contents of this work, except where otherwise noted, is licensed under a Creative Commons Attribution 4.0 International license.

Todo o conteúdo deste trabalho, exceto quando houver ressalva, é publicado sob a licença Creative Commons Atribição 4.0.

Todo el contenido de esta obra, excepto donde se indique lo contrario, está bajo licencia de la licencia $\underline{\text { Creative }}$ Commons Reconocimento 4.0. 


\section{Capítulo 3 \\ Ecuador, escenario dinámico, entre la continuidad y la transición. De la hegemonía del neoliberalismo a la construcción de una economía social y solidaria}

Caracterización del contexto ecuatoriano

Revolución ciudadana, un estado nación, entre la soberanía y la permanencia en el capitalismo global

En enero de 2015 el gobierno de la Revolución Ciudadana celebró ocho años de su ascenso y consolidación, como fuerza política, con representación mayoritaria en todos los poderes del Estado y centrada en la figura del presidente Rafael Correa.

$\mathrm{Al}$ parecer, dicho posicionamiento (sin paralelo en la historia del país) se extenderá por algunos años; lo que se puede inferir de las enmiendas ${ }^{27}$ que se han planteado en la Asamblea Nacional para modificar el texto de la Constitución. Estas enmiendas permiten que el actual gobierno o cualquier candidato pueda ser reelegido sin limita-

27 http://especiales.elcomercio.com/documentos/2014/11/Sentencia_Corte.pdf 
ción alguna, dando lugar a la figura de "reelección indefinida". Similares cambios se establecieron en países como Venezuela, Bolivia y Cuba.

Ecuador ha iniciado un acelerado proceso modernizador donde el gobierno que se autodenomina de la "revolución ciudadana”, busca devolver la centralidad al Estado, mediante la inversión pública y el control de los diversos sectores del país: organizaciones sociales, medios de comunicación, sectores productivos, de servicios, estratégicos, entre otros. Complementariamente, las estrategias se expresan con matices populistas y nacionalistas; esto último expresado en acciones como el cierre de la base norteamericana de la ciudad de Manta al terminarse el plazo establecido, que en condiciones similares a las de los anteriores gobiernos, se hubiera renovado. Otro ejemplo es el proceso de renegociación de los acuerdos con empresas petroleras y telefónicas, a partir de una posición soberana. En cuanto al populismo, es posible destacar la continuidad de acciones como el otorgamiento de subsidios y bonos de desarrollo humano a los sectores menos favorecidos económicamente, así como la construcción de imaginarios que polarizan a la sociedad entre individuos a favor o en contra de la revolución, mientras los grupos de poder continúan sin mayor desmedro de sus beneficios.

El evidente salto cualitativo producido en esta etapa, en comparación con gobiernos anteriores, deja entrever que la acción del gobierno actual deja un saldo positivo en cuanto a ámbitos como salud, educación, investigación e inclusión social. En general, la inversión social ha sido incrementada sustancialmente y se han reorientado los recursos públicos resultado de actividades como la extracción petrolera, el incremento en la recaudación de impuestos y las exportaciones y los préstamos de gran cuantía (como los que se han acordado con China). Estos recursos han sido redireccionados a espacios como la inversión social, el desarrollo de los sectores estratégicos como el de energía y la consolidación del aparato burocrático actual. 
Esta primera constatación es la que se presenta en la mayoría de mensajes oficiales, en los que se enfatiza el éxito de la revolución ciudadana. Basta revisar el artículo que circuló en Telesur, ${ }^{28}$ con motivo de la celebración de los ocho años de revolución ciudadana. Los datos que se presentan son alentadores y en la mayoría de los casos triunfalistas.

La pobreza en el país en el último período, disminuyó al $22,5 \%$ así como la desigualdad se redujo en 7 puntos de acuerdo el coeficiente de Gini, en un porcentaje mayor al de la región, que descendió 2 puntos. La inversión en educación alcanza el 2,2 por ciento del PIB, ubicando nuevamente al país entre los de inversión más alta en la región. El crecimiento económico llegó al 4,3\%, cifra elevada en relación con el crecimiento de la región que fue del 3,2\%. Es posible identificar nuevos datos, no obstante, la tendencia al incremento de la inversión pública y del crecimiento económico se mantienen.

Por otro lado, es importante no perder de vista que para analistas y cientistas sociales, el desarrollo del Ecuador se realiza conjuntamente con el modelo económico y político hegemónico, ante el cual la Constitución de 2008 planteó caminos diversos y alternativos: otra sociedad, economía y participación, fundamentados en el Buen Vivir, en el Sumak Kawsay. No obstante, en la práctica, las decisiones de gobierno se mantienen entre la continuidad y el cambio.

Para Boaventura de Sousa Santos, el ejemplo del parque nacional Yasuní, le permite presentar la disyuntiva del actual gobierno, en el que sacrificar su biodiversidad por la necesidad de contar con recursos para las inversiones previstas y además, lograr la financiación de países como China, es parte de los sacrificios que se deben hacer. Este predicamento, evidencia la valoración en relación con la oposición que diversos colectivos y organizaciones ciudadanas plan-

28 http://www.telesurtv.net/analisis/Ecuador-8-anos-de-Revolucion-Ciudada na-20150115-0097.html 
tearon, los que son vistos y tratados como obstáculos. La polarización en la sociedad recibe incentivos constantes de los medios de comunicación y de la misma estrategia de comunicación del presidente y del gobierno. El riesgo de la criminalización de la protesta social es creciente y el etiquetamiento de quien está a favor o en contra también se ha convertido en una práctica cotidiana. Lo trágico radica en la aparente encrucijada del gobierno en la construcción de un Estado nación en tiempos del neoliberalismo global, en que la opción es tomar todo recurso disponible para financiar el cambio esperado, aún con el riesgo que tal cambio sea hipotecado a los mismos grupos de poder de los que se busca distanciarse, como expresa de Souza:

La política tiene que asumir un carácter sacrificial, dejando de lado lo que más valora para que un día pueda rescatarlo. Así, es necesario intensificar la explotación de recursos naturales (minería, petróleo, agricultura industrial) antes de que sea posible depender menos de ellos. Para ello, es preciso llevar a cabo una agresiva reforma de la educación superior y una vasta revolución científica basada en la biotecnología y la nanotecnología para crear una economía del conocimiento a medida de la riqueza de la biodiversidad del país. Todo esto sólo dará frutos (tenidos como ciertos) muchos años después (de Souza, 2015, p. 183).

Como se mencionó antes, el desarrollo propuesto por el gobierno actual se fundamenta en una redistribución de la renta sin precedentes y a la vez sin menoscabar el ingreso de los grupos económicamente y políticamente poderosos. Estas continuidades, como la concentración de la riqueza, de las ventas, utilidades y del sistema financiero en grupos económicos que históricamente han dominado el país; generan preocupación por la inconsecuencia de las realidades con los discursos y, sobre todo, con lo previsto en la Constitución en relación con que el Ecuador sea el país del Sumak Kawsay, del Buen Vivir. El crecimiento de tal concentración de recursos en manos de grupos de poder puede ser identificado en los siguientes datos: 
El incremento de los ingresos de los grupos económicos entre 2010 y 2013 alcanzó los 76721 millones de dólares, 98,4\% más alto que en el periodo 2004-2006. La utilidades se duplicaron y llegaron a diez mil millones de dólares y las de la banca privada, fueron de $84,2 \%$ superiores que en el 2004-2006. El promedio anual en siete años de gobierno, es 285 millones anuales de utilidades. El consumismo también se incrementó con el desarrollo consecuente de los sectores empresariales relacionados. En resumen, entre 2010 y 2013, las empresas de comunicación incrementaron sus ingresos en un $38 \%$, el sector inmobiliario $28,23 \%$, los seguros privados $21,27 \%$, manufacturas 20\% y supermercados 18\% (Acosta, 2014).

Otro aspecto clave está relacionado con el cambio de matriz productiva en el que la opción, al parecer, se centra en avanzar hacia una economía del conocimiento. En este sentido, el modelo se construirá a imagen de países integrados plenamente al neoliberalismo global, como los denominados "tigres asiáticos" con los cuales se han acordado mega proyectos como Yachay (la universidad emblemática de tecnología y ciencia), opción que permite identificar otro aspecto del plan de ruta del gobierno actual.

La propuesta tecnocrática del Gobierno del presidente Correa responde a un intento por modernizar el capitalismo en el Ecuador. Inclusive, su propuesta de una economía sustentada en el conocimiento (inviable si se firma un TLC con la UE), corre el riesgo de reproducir inútilmente esquemas existentes en otros países y en otros tiempos. A lo sumo terminaría por alentar una (imposible) mutación del Ecuador en el "jaguar latinoamericano", en réplica del desarrollo capitalista de Corea del Sur o de Singapur. La confianza en la tecnocracia moderna parece ilimitada, tanto que en el Gobierno ni siquiera se dan el trabajo de al menos estudiar las experiencias de otras épocas, como fue la industrialización vía sustitución de importaciones de inspiración cepalina y dependentista (Acosta, 2014).

Al finalizar este primer acercamiento, el objetivo es caracterizar el escenario del país en el que se desarrolla la nueva instituciona- 
lidad de la economía social y solidaria. Enfatizando, la dicotomía del momento actual en que, si bien existe un desarrollo importante del país, las continuidades relacionadas con el modelo hegemónico se mantienen e incluso se profundizan y consolidan.

\section{Las continuidades en la mente de la gente}

A finales del 2013, la Secretaría Nacional de Educación Superior, Ciencia y Tecnología (SENESCYT) con apoyo de la Red Infodesarrollo, ${ }^{29}$ realizó talleres en 24 ciudades del país, contactando a mil personas de las diversas regiones. Esta muestra tendría un margen de 3.1 de confianza. El objetivo era sensibilizar a la población acerca de la economía social del conocimiento, correlato de la economía social y solidaria, en lo concerniente a la búsqueda de salidas ante la hegemonía neoliberal y privatizadora.

La intención de los talleres fue difundir cómo la apertura del conocimiento podría ser clave en la calidad de vida de la población, en el reconocimiento de los conocimientos tradicionales y de las necesidades de lograr que la producción sea colaborativa, entre otros aspectos. Se explicaba en los diálogos que la mayoría de los productos y servicios que utiliza la ciudadanía se encuentran bajo licencias y patentes que hacen que sea limitado el acceso a la disponibilidad de recursos económicos. Dichas patentes y licencias restringían el acceso a servicios o productos que podían solucionar necesidades urgentes, como es el caso de medicamentos o determinar la calidad del acceso a la educación.

La mención de este proceso en el marco del documento puede ayudar a comprender las implicaciones del sistema hegemónico neoliberal en las prácticas y discursos de la población nacional. En la mayoría de los casos, las afirmaciones de la ciudadanía consultada

29 www.infodesarrollo.ec 
plantea que, aunque la salud, la educación y el conocimiento son derechos de todo ser humano, lograr cubrir dichos derechos pasa necesariamente por el factor económico; que aunque los servicios públicos se han incrementado, no cubren las necesidades de la población y que su total satisfacción está relacionada con el pago frecuente a servicios privados.

$\mathrm{Al}$ relacionar este aspecto con el crecimiento antes citado del sector de consumo, el escenario se caracteriza por su orientación hacia el neoliberalismo, lo cual es lógico e incluso obvio. Lo complejo es identificar, en la construcción de la institucionalidad de economía social y solidaria, el planteamiento de alternativas que permitan al sector involucrado desarrollarse significativamente y a la par de un contexto en que prima el consumo.

Para contar con elementos de juicios suficientes, en los siguientes apartados se realizará una revisión del contexto regional y nacional en relación con la economía social y solidaria.

\section{Economía social y solidaria en la región}

\section{El giro a la izquierda, las expectativas y las realidades}

La economía social y solidaria se desarrolla en la región, no solo como un contradiscurso al capitalismo global, sino como una reacción a la situación de pobreza y exclusión, resultado de la propia hegemonía del sistema.

Esta reacción originó, diversas prácticas que Cotera (2008) caracteriza, en su estudio Economía Social en América Latina, que para las necesidades de este documento permite comprender la diversidad y profundidad de dichas prácticas, relacionadas generalmente con la vida cotidiana, no con la acumulación o el consumismo. 


\section{Experiencias de economía solidaria}

Cuadro 7

Experiencias de economía solidaria

\begin{tabular}{|c|c|c|c|c|}
\hline $\begin{array}{l}\text { Las prácti- } \\
\text { cas econó- } \\
\text { micas co- } \\
\text { munitarias }\end{array}$ & $\begin{array}{l}\text { Las coopera- } \\
\text { tivas, aso- } \\
\text { ciación de } \\
\text { individuos }\end{array}$ & $\begin{array}{l}\text { Las asocia- } \\
\text { ciones, agru- } \\
\text { pamiento de } \\
\text { personas }\end{array}$ & $\begin{array}{l}\text { Las organi- } \\
\text { zaciones no } \\
\text { gubernamen- } \\
\text { tales (ONG) }\end{array}$ & $\begin{array}{c}\text { Otras formas } \\
\text { de organización } \\
\text { económica social } \\
\text { solidaria }\end{array}$ \\
\hline $\begin{array}{l}\text { Presentes en } \\
\text { comunida- } \\
\text { des nativas, } \\
\text { indígenas y } \\
\text { campesinas, } \\
\text { recreadas en } \\
\text { las zonas ur- } \\
\text { banas popu- } \\
\text { lares, y que se } \\
\text { expresan en } \\
\text { compartir el } \\
\text { uso común de } \\
\text { los recursos y } \\
\text { la realización } \\
\text { de trabajos } \\
\text { colectivos en } \\
\text { forma comu- } \\
\text { nal y solidaria }\end{array}$ & $\begin{array}{l}\text { Unidos para } \\
\text { emprender } \\
\text { acciones eco- } \\
\text { nómicas que } \\
\text { buscan resol- } \\
\text { ver problemas } \\
\text { específicos, } \\
\text { compartiendo } \\
\text { riesgos y bajo } \\
\text { una filosofía } \\
\text { de ayuda } \\
\text { mutua y de } \\
\text { cooperación } \\
\text { solidaria }\end{array}$ & $\begin{array}{l}\text { Organizados } \\
\text { para desarro- } \\
\text { llar acciones } \\
\text { socioeconómi- } \\
\text { cas en bene- } \\
\text { ficio común } \\
\text { y también, en } \\
\text { muchos casos, } \\
\text { en colabora- } \\
\text { ción con su } \\
\text { comunidad } \\
\text { y/o algún } \\
\text { sector social }\end{array}$ & $\begin{array}{l}\text { Instituciones } \\
\text { promotoras } \\
\text { y soportes } \\
\text { técnicos de } \\
\text { proyectos de } \\
\text { desarrollo en el } \\
\text { campo y secto- } \\
\text { res populares } \\
\text { de las ciudades, } \\
\text { sustituyendo en } \\
\text { muchos casos } \\
\text { la labor del } \\
\text { Estado ante la } \\
\text { ausencia de éste } \\
\text { en esos lugares }\end{array}$ & $\begin{array}{l}\text { Las sociedades de } \\
\text { solidaridad social, } \\
\text { organizaciones } \\
\text { campesinas, cajas } \\
\text { de ahorro, empresas } \\
\text { recuperadas por } \\
\text { sus trabajadores, } \\
\text { agricultura familiar, } \\
\text { agricultura orgáni- } \\
\text { ca, proyectos comu- } \\
\text { nitarios, colectivos } \\
\text { informales, grupos } \\
\text { de crédito solidario, } \\
\text { clubes de trueque, } \\
\text { bancos comunita- } \\
\text { rios, cadenas soli- } \\
\text { darias, iniciativas } \\
\text { de comercio justo y } \\
\text { comunitario, tu- } \\
\text { rismo social soli- } \\
\text { dario, comedores } \\
\text { populares, clubes } \\
\text { de madres, comités } \\
\text { de vaso de leche, } \\
\text { talleres de pro- } \\
\text { ducción, empresas } \\
\text { mixtas, iniciativas } \\
\text { municipales para el } \\
\text { desarrollo local }\end{array}$ \\
\hline
\end{tabular}

Fuente: Elaboración propia con base en documento de Cotera (2008)

Otro aspecto importante está relacionado con la conformación de organizaciones y redes de Economía social y solidaria en la Latinoamérica. Las más antiguas datan de finales de los años 90 en Perú, Brasil y México. La meta inicial de estas redes fue aglutinar, or- 
ganizar, coordinar, la acción de diversos actores distribuidos por los territorios y que coincidían en acciones y enfoques. Conforme transcurrió el tiempo se hizo preciso diseñar espacios de mayor reflexión y debate que dieran prominencia al proceso iniciado.

La articulación de iniciativas de economía solidaria en el ámbito internacional tuvo su hito en julio de 1997, en la ciudad de Lima, cuando más de 200 experiencias provenientes de 32 países de los cinco continentes se reunieron en el Primer Simposio de Globalización de la Solidaridad (Cotera, 2008).

Como se puede comprender el proceso avanzó en la lógica de los encuentros internacionales de intercambio y la conformación de redes regionales y continentales que aglutinaran otras redes nacionales. Tal así que en 2001, se constituye la Red Intercontinental de Promoción de la Economía Social Solidaria (RIPESS). Todas estas experiencias buscaban alternativas a los efectos de la crisis del modelo neoliberal.

\section{Exclusión y pobreza, el escenario regional de la economía social $y$ solidaria}

La profunda contradicción presente en la región está marcada por el empobrecimiento de entre el 35\% y 60\% de la población, y por la concentración de la riqueza más alta del mundo (Coraggio, 2013). Este constituye el escenario en el que se desarrollan diversas expresiones y prácticas contra hegemónicas, de economía social y solidaria en diversos países de la región.

Las poblaciones latinoamericanas empobrecidas, están conformadas por "la masa de excluidos del mercado de trabajo formal que resultó de la acción neoliberal de las últimas tres décadas (que) vino a sumarse a la masa que ya existía de trabajadores por cuenta propia, precarios, excluidos o autoexcluidos del sistema de derechos laborales" (Coraggio, 2013, p. 1). 
Lo anterior no hace más que evidenciar que entre los retos de la economía social y solidaria se identifica el integrar individuos y colectivos en situaciones de extrema exclusión, cuyas necesidades no son cubiertas de ninguna manera y frente a los que no se expresan relaciones simétricas de solidaridad, sino más bien de asistencialismo o filantropía. En otras palabras, ¿de qué manera multiplicar las prácticas de economía social y solidaria en situaciones de gran exclusión, frente a la cuales las respuestas públicas pasan por la caridad o la mera compensación?

Por otro lado, la región ha experimentado un incremento de sus exportaciones, la mejora de los sistemas tributarios y el desarrollo de programas compensatorios al interior de la mayoría de países; elementos que de alguna manera alivian la tensión que evidencia la necesidad de alternativas al sistema económico, frente a un aparente debilitamiento del neoliberalismo. Lo paradójico estriba en que bajo la coyuntura actual, los países de la región cuentan con que sus ingresos se mantendrán como resultado de la extracción de recursos naturales, lo que desvía la atención de la construcción de alternativas radicales económicas.

Los espacios de reflexión e intercambio, como el Foro de Porto Alegre, que lograron notoriedad y el posicionamiento de problemáticas regionales en su momentos, también encontraron dificultades en lograr acuerdos concretos de acción entre los diversos colectivos participantes y, aunque su reflexión en relación con la economía social y solidaria se amplió a diversos ámbitos y continúa, su paso es lento hacia la convergencia. Lo anterior obedece quizás a que la mayoría de los colectivos cuentan en sus países con problemáticas que limitan la capacidad de construir agendas comunes duraderas, o presentan limitaciones propias de la construcción, participación y organización social.

No obstante, el trabajo de las redes y organizaciones, de los movimientos sociales y también la respuesta frente a la crisis del sistema, dio como resultado cambios políticos al interior de países de la región 
que conllevaron a transformaciones de signo político y una oscilación hacia la izquierda y centro izquierda de la mayoría de los gobiernos.

Este nuevo escenario provocó que las políticas de Estado se orientaran más hacia lo popular, con la modificación de la legislación y el desarrollo de una nueva institucionalidad con especialización en la economía social y solidaria.

Coraggio (2014) ha realizado un estudio comparativo en cinco países, referente a las similitudes y contrastes existentes entre las instituciones públicas especializadas en economía social y solidaria. Los países en cuestión son Argentina, Brasil, Bolivia, Ecuador y Venezuela.

En el caso de Argentina y Brasil, los ajustes son menores en comparación al resto y afectan el marco legal existente. Argentina presenta una mayor práctica de inclusión social, de asistencia y compensación. Por su parte, en Brasil existe un proceso organizativo social que permite empujar los cambios en legislación. En mayor medida, los retos obedecen a conciliar las diversas agendas entre las organizaciones sociales participantes y el gobierno de raíz social; sin embargo, se evidencia que se actúa en diversas escalas de negociación, más orientado a lograr compensaciones que cambios de fondo. Un aspecto clave se relaciona con la sostenibilidad del proceso, incluso en relación con la legislación; como ejemplo, en Porto Alegre donde el PT logró por muchos años establecer como política pública el presupuesto participativo, pero al cambiar de manos el gobierno del Estado, la política fue transformada. En todo caso, las acciones en Brasil se orientan más hacia una co-construcción de la política pública.

En el caso de Bolivia y Ecuador, los cambios propuestos se encuentran vinculados con los procesos constituyentes $y$, por ende, son parte de la perspectiva bajo la cual la nación es construida a partir de una historia de resistencia o sobrevivencia económica, y por la profundidad del cambio propuesto tomará años para lograr la transición (Coraggio, 2014). En relación con Venezuela, el país comparte 
también el proceso de inclusión de la economía social y solidaria en su proceso constituyente; sin embargo, su proyecto está marcado por el cambio constante y la búsqueda de sentido y lugar de la economía social y solidaria en el proceso de la Revolución Bolivariana.

Cabe decir que en todos los países se evidencia la tensión entre la acción, para dar solución a la integración de colectivos excluidos mediante programas sociales, y la construcción de una estructura de la institucionalidad que permita construir una economía centrada en la solidaridad.

\section{La economía social y solidaria en el Ecuador}

\section{La situación de la economía social y solidaria en el país}

En los postulados planteados con antelación, se evidencia la presencia de contrastes que caracterizan el contexto en el que se desarrolla la economía social y solidaria, los actores públicos y de la sociedad civil. En este sentido, el abordaje de los conceptos de cambio y continuidad, resulta adecuado para la caracterización de este escenario, político, económico, social y cultural.

En Ecuador, como se lo anticipa en el título del capítulo, la realidad sugiere un contexto complejo, en el que coexisten acciones de cambio de mano de la inversión pública y por otro lado, el continuismo de la presencia de poderes hegemónicos en todos los ámbitos del país, en particular los económicos; lo que hace que las iniciativas de economía social y solidaria no sean percibidas en su real dimensión.

En el país la primera constatación de la paradoja expresada en el cambio y la continuidad se expresa en el texto de la Constitución, que al referirse al sistema económico en su totalidad, menciona que éste es social y solidario, conformado por las formas de economía pública, privada, mixta, popular y solidaria (Asamblea Constituyente, 2008). Ésta última, la popular y solidaria, incorpora a los sectores cooperati- 


\section{1}

vos, comunitarios y asociaciones. La paradoja radica en que los avances en cuanto a legislación se concentran en el sector de la economía popular y solidaria y no en el sistema económico, que siendo también social y solidario, precisa de cambios profundos en su totalidad. Es posible que parte de estos cambios radicales, sean parte de legislaciones como el Nuevo Código Monetario y Financiero (Banco Central del Ecuador, 2014), aspecto que sería objeto de otro estudio.

No obstante, para los fines de la investigación se centrará la atención en lo que a nivel nacional se conoce como economía popular y solidaria, la legislación y sus entidades, así como en los actores sociales más relevantes.

La economía popular y solidaria, tiene sus orígenes en las prácticas ancestrales que han sido fundamento del crecimiento y de su consolidación cultural, social, política y económica, en particular de la región Andina. Este aspecto resulta clave dado que, al parecer, en la construcción de institucionalidad las prácticas de economía social y solidaria podrían ser consideradas como un resultado de la acción gubernamental y no como son en realidad: originadas en vertientes muy antiguas de la región Andina, en las que es evidente que las prácticas económicas no necesariamente se construyeron en el intercambio monetario como finalidad; por ejemplo el "cambeo", la minga, el randi randi, etc.

En tal orden, el desafío radica en dotar a la acción pública y privada del sentido de la economía social y solidaria, es decir, de la comprensión de que es una economía para la vida; en la que los actores, más que competidores son parte de un todo, al igual que la naturaleza. Debido a la convergencia de dos realidades naciona-

30 En Pimampiro, el "cambeo" forma parte de sus tradiciones más antiguas. Su expresión más importante se realiza durante los días de semana santa, en la que la población se reúne y realiza un intercambio de productos sin dinero, los actores vienen de diversos grupos culturales y poblaciones. 
les: una antigua, expresada en acciones de comunidades y personas, de organizaciones sociales, que pueden ser comprendidas como de economía social y solidaria y por otro lado, una institucionalidad naciente, cuyo fin es la de construir desde el Estado un sector económico nuevo, popular y solidario, en el que cohabiten las experiencias de cooperativas, asociaciones y comunitarias; el Estado ecuatoriano diseñó una estructura destinada a fortalecer y dinamizar la economía popular y solidaria.

Es posible mencionar que la construcción de dicha institucionalidad establecida además constitucionalmente, es el punto más alto de un recorrido en el que las primeras noticias tienen que ver con legislación para la promoción y regulación de cooperativas.

Luego de aprobada la Constitución de 2008, tomó tres años la aprobación de la Ley Orgánica de Economía Popular y Solidaria (LOEPS) y poco después fue aprobado su Reglamento. Para investigadores como Coraggio (2014) este es el cuerpo de ley más avanzado de la región.

En el marco de la LOEPS, se denominan a las organizaciones de la economía popular como las orientadas a:

(...) satisfacer necesidades y generar ingresos, basadas en relaciones de solidaridad, cooperación y reciprocidad, privilegiando al trabajo y al ser humano como sujeto y fin de su actividad, orientada al buen vivir, en armonía con la naturaleza, por sobre la apropiación, el lucro y la acumulación de capital (Presidencia de la República, 2011).

Las finalidades de las organizaciones de economía popular y solidaria, son las siguientes:

- La búsqueda del buen vivir y del bien común.

- La prelación del trabajo sobre el capital y de los intereses colectivos sobre los individuales.

- El comercio justo y consumo ético y responsable. 
- La equidad de género.

- El respeto a la identidad cultural.

- La autogestión.

- La responsabilidad social y ambiental, la solidaridad y rendición de cuentas.

- La distribución equitativa y solidaria de excedentes (Presidencia de la República, 2011).

Resulta evidente el intento por describir aquello que distingue una acción económica popular y solidaria, de otras. A partir de las finalidades, es posible reconocer una serie de principios y valores que deberían fundamentar toda la economía.

Se define además que la Economía Popular Solidaria se integra por asociaciones, cooperativas y comunidades, y sobre las Unidades Económicas Populares (UEP), plantea:

(...) las que se dedican a la economía del cuidado, los emprendimientos unipersonales, familiares, domésticos, comerciantes minoristas y talleres artesanales; que realizan actividades económicas de producción, comercialización de bienes y prestación de servicios que serán promovidas fomentando la asociación y la solidaridad (Presidencia de la República, 2011).

Adicionalmente, la Ley incluye al sector de las cooperativas y asociaciones y define el establecimiento de nuevas instituciones que velarán por el control, regulación y financiación del sistema de finanzas y seguro de depósitos. Siendo así, las entidades participantes de la economía popular y solidaria son las que se muestran a continuación:

De este modo la Ley define que el ámbito de la economía popular y solidaria, cubre como un paraguas a las cooperativas, asociaciones, comunidades y a las unidades económicas populares; entidades y expresiones que se distinguirán de otros actores económicos porque sus finalidades son sociales y solidarias, al no buscar acumulación y no poner al dinero como principal fin sino al trabajo. Sin 
embargo, esta finalidad tan coherente con el espíritu de la constitución y del Sumak Kawsay, sólo involucra a los actores mencionados, no a todo el sistema económico. Otro aspecto a considerar tiene que ver con que tal definición se posiciona contra todo el sistema hegemónico, de tal manera que a decir de Coraggio: Las movilizaciones que acompañan los procesos de definición de estos cambios muestran que la institucionalización de nuevas formas de economía solidaria enfrenta y deben vencer fuerzas e intereses poderosos, lo que demanda un proyecto no sólo social y económico sino también político (Coraggio, 2013).

\section{Gráfico 2}

Actores participantes en el sector de la economía popular y solidaria

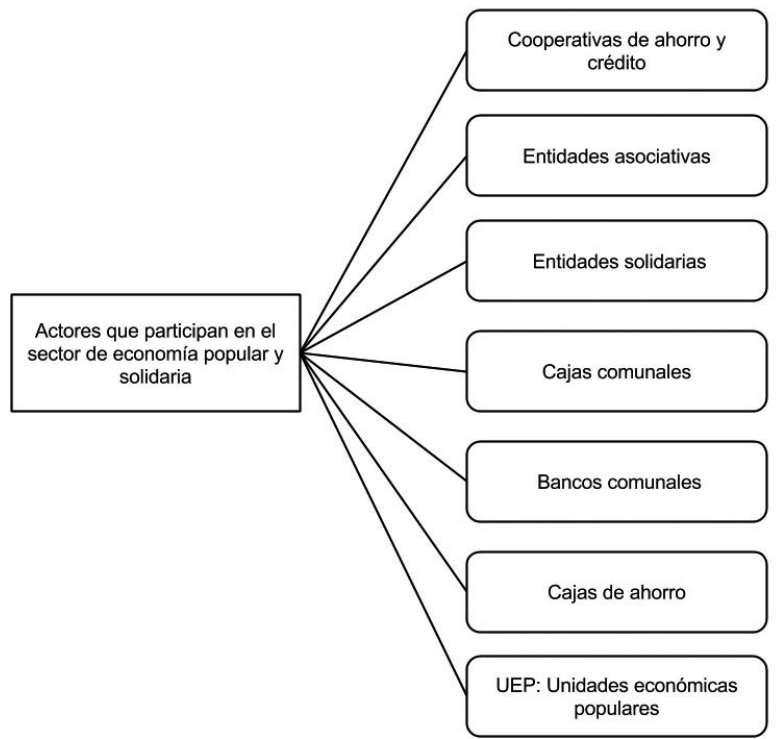

Elaboración: autor

Aunque el cambio propuesto sólo contemple a una parte de los actores económicos del país, se necesita de apoyo político para 
105

lograr las finalidades previstas; por ejemplo, situar el trabajo y no la acumulación del capital como fin es una afirmación no menor, que precisa de cambios radicales en el Estado.

\section{La economía social y solidaria, los actores de la sociedad civil: diversidad y capilaridad}

Como se puede evidenciar, el sector de la economía social y solidaria es complejo y dinámico; el mismo está conformado por una amplia gama de actividades económicas, que van desde microempresarios a productores agrícolas, trabajadores informales y madres cuidadoras en los Centros Infantiles del Buen Vivir (CIBV). Algunos datos permiten comprender su rol en la economía nacional: existen alrededor de 1 millón de unidades de producción, servicios y comercio, que representan del 10\% al 15\% del PIB. Asimismo, se identifican aproximadamente 22800 organizaciones jurídicas, aunque no todas son de economía y solidaria (Andino, 2012). Como parte de estas cifras, el sector de cooperativas agrupa alrededor de cuarenta. La entidad que tiene por mandato su financiamiento es la CONAFIPS, que hasta 2014 colocó en las cooperativas la cifra de USD\$ 600 millones de dólares fortaleciendo de esta forma alrededor de 581391 emprendimientos. En relación con la producción agropecuaria, las unidades de producción agrícolas (UPAS) están conformadas por el $84 \%$ de entidades de agricultura familiar campesina, que proveen el 60\% de los productos de la canasta básica (Andino, 2012).

De igual manera, se puede observar que la presencia de las actividades económicas está fuertemente vinculada con los territorios, lo que permite que el éxito o fracaso repercuta en las realidades de hogares concretos.

Sin embargo, existen otro tipo de actores vinculados con la economía social y solidaria en el país y que necesitan particular atención: las organizaciones y asociaciones sin fines de lucro que en mu- 
chos casos son las que reúnen la experiencia de años de trabajo en el sector de economía social y solidaria.

A continuación se hará referencia a algunos actores que por su trayectoria, compromiso o incidencia en la economía y política del país, son relevantes para este estudio.

En este sentido, vale destacar la actividad del Movimiento de Economía Social y Solidaria del Ecuador (MESSE), ${ }^{31}$ espacio de trabajo y reflexión, que busca la articulación de los actores de economía social y solidaria del país. Uno de los aportes del movimiento es la investigación acerca de los Circuitos Económicos Solidarios (CES), estrategia clave para el aprovechamiento óptimo de la vinculación con los territorios, el fortalecimiento del desarrollo endógeno y la construcción de relaciones horizontales entre los actores económicos en los intercambios económicos y no económicos (trueques, randi-randi, mingas, etc.).

El MESSE es un colectivo social que empezó a estructurarse en 2007 ante la necesidad de un espacio de encuentro y articulación de diferentes dinámicas, experiencias, proyectos, prácticas y procesos urbanos y rurales que realizaran actividades vinculadas a la economía popular, comunitaria, del cuidado, social, solidaria, del trabajo, alternativa, etc., y que de manera conjunta buscaran fomentar formas de vida que aporten a la construcción de un nuevo modelo de desarrollo (MESSE, 2008).

El MESSE es un colectivo social que promueve, valora y construye diálogos, conocimientos y saberes mediante un aprendizaje comunitario; generando, difundiendo y posicionando propuestas a nivel local, nacional, regional y global para transformar la sociedad 
en el marco de una economía de solidaridad, celebrando la vida y alcanzar el Sumak Kawsay ( buen vivir) (MESSE, 2008).

Durante el encuentro de trabajo en Guaslán desarrollado en 2010, en las instalaciones del MAGAP (Chimborazo), se construye la definición de economía social y solidaria, que hasta la actualidad orienta el trabajo del movimiento. En tal orden, se definió como:

(...) una forma de convivencia entre las personas y la naturaleza que satisface las necesidades humanas y garantiza el sostenimiento de la vida, con una mirada integral, mediante la fuerza de la organización, aplicando los saberes y las prácticas ancestrales para transformar la sociedad y construir una cultura de paz (MESSE, 2012).

El desarrollo del movimiento también originó aprendizajes, en particular sobre la necesidad de mantener encuentros frecuentes en diversos lugares del país que permitieran conocer nuevas experiencias y actores de economía social y solidaria. En el origen del movimiento, el apoyo de entidades como AVINA y VECO, la Fundación Maquita Cushunchic Comercializando como Hermanos (MCCH), la Red Latinoamericana de Comercio Comunitario (RELACC), REDESOL de Cuenca y el Colectivo Agroecológico del Austro, fue clave para dar los primeros pasos.

El nacimiento del movimiento, poco tiempo antes de la Constituyente de 2007, permitió que se pudieran presentar aportes para la nueva Constitución y que miembros del movimiento participaran en talleres relacionados con la Constituyente. No obstante, dicha actividad dividió las fuerzas del movimiento entre el activismo y la necesidad de dar forma al movimiento, tal y como se desprende de la lectura del trabajo de Katiuska Aguilar (2014). No obstante el MESSE avanzó en la definición de sus objetivos y principios, así como en la definición de una estructura mínima, como se muestra a continuación: 
Identidad: "Somos un movimiento que genera propuestas alternativas que dan respuesta a la realidad, desarrollando acciones conjuntas y con una estructura ágil” (MESSE, 2008).

Cuadro 8

Ejes y estrategias del MESSE

\begin{tabular}{|c|c|}
\hline Ejes & Estrategias \\
\hline Espacio de intercambio & $\begin{array}{l}\text { Ferias, instancias y espacios de intercam- } \\
\text { bio. Socialización y enseñanza - aprendi- } \\
\text { zaje vivencial de las diferentes experiencias } \\
\text { de espacios de intercambio. }\end{array}$ \\
\hline Soberanía alimentaria & $\begin{array}{l}\text { Interiorización de la soberanía alimentaria } \\
\text { a través de procesos de formación, capaci- } \\
\text { tación, intercambio de saberes y reflexión. } \\
\text { Campaña (difusión, comunicación, in- } \\
\text { formación y reflexión) sobre la soberanía } \\
\text { alimentaria hacia la ciudadanía. }\end{array}$ \\
\hline $\begin{array}{l}\text { Articulación, integración y gestión del } \\
\text { MES1 }\end{array}$ & $\begin{array}{l}\text { Estructura organizativa del MES apoya, } \\
\text { promociona e integra a nuevos sectores y } \\
\text { actores a nivel nacional. } \\
\text { Procesos de diálogo, reflexión y produc- } \\
\text { ción de saberes entre los } \\
\text { diferentes actores del MIES }\end{array}$ \\
\hline Incidencia Política & Plan de incidencia política \\
\hline
\end{tabular}

Fuente: (MESSE, 2008)

Elaboración: autora

En la actualidad, el MESSE define como ejes de acción:

- Interaprendizaje y diálogo de saberes

- Comunicación y articulación

- Incidencia política

- Autogestión y proyectos (MESSE, 2012).

Este movimiento se organiza a partir del Consejo nacional, elegido cada dos años. Además cada uno de los ejes es materializado por una Comisión. El MESSE se organiza a partir de tres zonas: nor- 
te, centro y sur, aunque se reconoce que tiene mayor presencia en la sierra ecuatoriana, buscando fortalecer su acción en las demás regiones del país. Finalmente, cada año se convoca un encuentro nacional que permite presentar el trabajo realizado y retroalimentarlo.

El aporte más importante del MESSE se relaciona con el desarrollo teórico de los Circuitos Económicos Solidarios más tarde llamados Circuitos Económicos Solidarios Interculturales. Gonzalo Silva, docente e investigador chileno, en el periodo 2010-2012, desarrolló una investigación en ese sentido: "Circuitos Económicos Solidarios y puesta en valor del Patrimonio Cultural”, esta investigación se financió con fondos de la Unión Europea y fue llevada a cabo en los países de Chile, Paraguay y Ecuador. Los resultados para Ecuador fueron presentados en la Universidad Politécnica Salesiana, que constituía una de las entidades promotoras del estudio, como lo plantea Verónica Andino en su investigación (Andino, 2013).

Este proceso permitió llegar a una definición colectiva de los CES como:

(...) un conjunto articulado de agentes socioeconómicos que viven los principios de la Economía Solidaria, en donde el Factor "C" de la asociatividad está presente y activo a lo largo de todo el proceso económico. Los CES son intercambios de unos a otros, en un movimiento circular de relaciones responsables y recíprocas" y como "un instrumento que ayuda en la articulación de las redes y movimientos de Economía Solidaria, que vincula los aspectos económicos y socioculturales de cada territorio, para la visibilización de esta nueva economía... que ya existe (Silva, 2012).

Esta relación se origina en localidades particulares aunque pueden proyectarse a zonas mayores siempre que "se vehiculen identidades y sentidos en un movimiento que reconoce diversidad e interculturalidad" (Silva, 2012). 
Un breve comentario sobre este punto permite poner en cuestión los sentidos presentes en cada apreciación de los circuitos económicos solidarios, tanto en los que propone el IEPS y los que propone el MESSE. En efecto, existen coincidencias, pero el aspecto diferenciador es el territorio y las relaciones interculturales. Este diálogo no es posible sólo entre miembros de un mismo grupo, sino que es posible e imprescindible que se realice entre diversos actores de un territorio, que buscan que sus intercambios sean en el marco de la ética de la economía social y solidaria.

\section{Fondo Ecuatoriano Populorum Progressio (FEPP)}

Es una organización no gubernamental fundada en 1970, nacida en el seno de la iglesia católica y que goza con el auspicio de la Conferencia Episcopal Ecuatoriana, aunque prefieren la denominación de institución privada con finalidad social. Precisamente, esta finalidad está dirigida al desarrollo integral de los campesinos, aunque con el pasar de los años se ha expandido al trabajo en sectores urbano marginales del país.

Actualmente, es un grupo social integrado por 20 equipos interdisciplinarios con alrededor de 480 personas, que con su trabajo inciden en más de cien mil familias de casi todo el país, en 23 de las 24 provincias. El alcance del FEPP llega hoy a 550000 personas, dato que es necesario contrastar con la eficacia que en el presente tiene la entidad financiera que creó en 1997, Codesarrollo, hoy BanCodesarrollo.

- La organización cuenta con un despliegue en el país mediante las diez oficinas regionales, las que también ofrecen soporte a las empresas sociales:

- CAMARI, sistema solidario de comercialización, en Quito, Riobamba, Latacunga y Cuenca.

- FUNDER, escuela de formación empresarial, Monseñor Cándido Rada. 
- FEPP Construcciones-Agua y Vivienda, es para la construcción de viviendas rurales, obras de servicio comunitario e implementación de proyectos de agua potable y riego.

- PROTIERRAS, se encarga de la legalización y titulación de tierras y territorios.

- AGROIMPORTADORA FEPP, importa suministros y semillas para los campesinos.

- IMPREFEPP, imprenta del FEPP de contenidos técnicos y educativos.

- YURA FEPP, promueve el manejo sustentable de los recursos naturales.

- BANCO Desarrollo, antes CODESARROLLO, que presta el servicio de ahorro, crédito y finanzas a las organizaciones campesinas y entidades de la economía social y solidaria. Actualmente, el nuevo banco cuenta con una casa matriz en Quito, además de una sucursal al norte de la capital y 14 otras oficinas en varias provincias. Además, cuenta con 100000 clientes directos y 150000 indirectos, a través de las cooperativas asociadas.

El Fondo Ecuatoriano Populorum Progressio, cuenta ya con más de cuarenta años de trayectoria y proyectos diversos fuertemente vinculados con la ruralidad y los sectores más excluidos. La lista continúa con MCCH, que ha logrado ser referente de la exportación de cacao a nivel internacional, mediante una intrincada red de productores organizados. Entidades que suman su experiencia a la economía social y solidaria son Funorsal, en Salinas de Bolívar, Simiatug Samay, ERPE y muchas entidades más. Durante los últimos años dichas entidades y ONG, como VSF, VECO, Hegoa, Intercooperación, Utopía, han destinado también su acción al fortalecimiento de la relación entre los actores.

EL MOVIMIENTO INDÍGENA

Si bien el Ecuador es altamente dependiente de las importaciones, no es menos cierto que cuenta con un sector histórico de 
economía popular con fuerte peso del campesinado y las comunidades indígenas. Es interesante descubrir puntos de encuentros entre el Estado y el Movimiento Indígena para el desarrollo de la economía popular y solidaria, lo cual supondría una mirada sobre la historia y el presente de este actor político y social que, a su vez, representa otras organizaciones.

De acuerdo con el estudio de Phillip Altmann, el movimiento indígena en el Ecuador está compuesto por diferentes organizaciones indígenas que compiten entre sí por miembros y recursos (Altmann, 2014).

La competencia se establece entre organizaciones indígenas, al interior de las mismas y entre las más antiguas. Su presencia en el contexto histórico ecuatoriano, puede entenderse como relaciones dinámicas, si bien son posiblemente antagónicas, también de alianzas coyunturales ricas en procesos de aprendizaje políticos y sociales, que hacen del movimiento indígena un actor histórico clave en la construcción de la democracia de los últimos ochenta años.

Como se mencionó con anterioridad, el movimiento indígena es la suma de diversos actores que se constituyeron de acuerdo con los diversos momentos políticos y sociales del país. El primer actor en este sentido es la Federación Ecuatoriana de Indios (FEI) que se constituye en un Ecuador, de reformas agrarias y de ley de comunas, en el que actores políticos como el PCE y la CTE impulsan la organización de los indígenas. En este sentido, el origen del FEI tiene que ver con una lectura de la realidad en el que la lucha por la tierra, la defensa de los derechos de los trabajadores, de los campesinos, dan sentido a organizaciones gremiales, sindicales y campesinas; en estas últimas la presencia de la FEI plantea también la lucha indígena y cultural.

El momento más alto de la FEI fue en 1950, siendo un actor clave del IV Congreso, con 400 delegados de la Sierra. Diez años más tarde se evidenciaría su debilitamiento. En 2007 el CODENPE da 
cuenta de que la FEI cuenta con dos organizaciones de segundo grado en Chimborazo y Esmeraldas, con 5655 miembros (Altmann, 2014).

Confederación Nacional de Organizaciones Campesinas, Indígenas Y NEGRAS (FENOCIN)

Su origen está ligado también con la tensión entre el socialismo naciente en el Ecuador y la acción de la Iglesia Católica y el Partido Conservador. Era necesario un movimiento que no tuviera relación con las tendencias de izquierda, que agrupara a artesanos y obreros; el movimiento sería la Confederación Ecuatoriana de Obreros Católicos (CEDOC).

Sus acciones también se orientaron a aglutinar y organizar organizaciones del país para luchar por los derechos a la tierra y los derechos de los trabajadores. Logra un rápido crecimiento y en 1968 cambia su nombre a Federación Nacional de Organizaciones Campesinas (FENOC).

En 1970 debido a diferencias internas ligadas a las visiones más reformistas y de la democracia cristiana, se producen divisiones que originan que algunas de las organizaciones de la FENOC se separaran y se unieran a la ECUARUNARI.

En 1975, la FENOC realiza una alianza con el Partido Socialista, lo cual provoca un acercamiento a la lucha sindical urbana. Dos años más tarde, se conforma una plataforma de lucha conjunta en la que participaron la FENOC, la FEI y la ECUARUNARI, la cual se denominó "Frente Único de Lucha Campesina", que más tarde se renombró "Frente Único de Lucha Campesina e Indígena”. Sin embrago, ninguna de las dos experiencias tuvieron larga duración.

A principios de 1980 la FENOC era la organización campesina más grande del país. En esta época cambia su nombre a FENOC-I, que incluye por primera vez a los Indígenas. Pero de forma similar a lo que sucedió con la FEI, este apogeo fue también antesala de un debilita- 
miento que dura hasta mediados de 1990, marcado por la hegemonía de otro movimiento: la CONAIE, ante la cual la FENOC se ubica como opositora, por entenderse la única representación de los indígenas.

Como datos adicionales el nombre con el que se conoce al movimiento, fue definido en 1999. Años antes participó en el nacimiento de la CLOC y es miembro de la Vía Campesina.

La FENOCIN, tiene presencia en 18 de las 24 provincias del país, 61 organizaciones de segundo grado y 1200 organizaciones de base. En la actualidad es la organización indígena más cercana al gobierno actual.

Consejos de Pueblos y Organizaciones Indígenas Evangélicas del ECUADOR (FEINE)

Nace en 1980 en el seno del sector protestante, como resultado de la presencia de las iglesias evangélicas. Su crecimiento y consolidación se relacionan con este origen y con la facilidad frente a otros actores de contar con fondos internacionales. La FEINE, se constituye en un actor que trae consigo al debate político nacional la presencia evangélica indígena, aunque en el seno del movimiento indígena tal posición no fuera significativa.

\section{CONFEDERACIÓN DE NACIONALIDADES INDÍGENAS DE LA AMAZONÍA ECUATORIANA (CONFENIAE)}

También relacionada con la presencia de iglesias evangélicas, en este caso, en la Amazonía. Las organizaciones resultantes se constituyen a partir de la comprensión del hecho diferenciador de la etnia y la comuna. Este enfoque se distancia de los anteriores porque se hace fuerte en lo cultural, originario frente a los procesos homogeneizadores y en lucha abierta contra la asimilación de los pueblos amazónicos por parte del Estado ecuatoriano. Primero fueron organizaciones Shuar, luego aparecen las organizaciones provinciales, como las de Sucumbíos, Pastaza. Esta entidad, junto con la ECUA- 
RUNARI tuvo gran importancia en la construcción de la federación indígena nacional.

Confederación de Pueblos de la Nacionalidad Kichwa DEL ECUADOR (ECUARUNARI)

En 1972, nace la ECUARUNARI, organización de los kichwas ecuatorianos. Su origen tiene raíces en la iglesia católica post-concilio Vaticano II, que motiva la organización de la izquierda católica, en tiempos de la teología de la liberación. La ECUARUNARI se definió como movimiento clerical exclusivamente indígena.

Su eje de acción también fue la tierra y las demandas étnicas y el aporte esencial del movimiento fue la construcción de una plataforma de lucha a partir de la reivindicación de los derechos de los indígenas como ciudadanos y de su realidad cultural.

En 1980, con el apoyo de la CONFENIAE, se funda la CONACNIE, de la cual en 1986, nace la CONAIE.

CONFEDERACIÓN DE NACIONALIDADES INDÍGENAS DEL ECUAdOR (CONAIE)

Desde su nacimiento se planteó como meta unir en una misma lucha dos diversos enfoques: el de clase y el étnico, dimensiones en constante cercanía y disputa. Las demandas del movimiento se condensan en:

- La devolución total de las tierras indígenas en forma de propiedad comunitaria.

- La defensa de las culturas indígenas, incluida la medicina tradicional.

- Educación y concientización de los indígenas en programas de educación bilingüe.

- La búsqueda de alianzas y financiamiento para constituir un banco indígena. 
- La coordinación de las políticas de todas las organizaciones indígenas.

Su actuar en el país se ha consolidado mediante acciones colectivas de gran magnitud, como los levantamientos y manifestaciones. Representa a los indígenas como tales y como campesinos frente los conflictos de tierra.

En 1996, se funda el Movimiento de Unidad Plurinacional Nuevo País y es parte de la Coordinadora de Movimientos Sociales. Este hecho marca el momento en que el movimiento se hace presente en el escenario partidista del país, aglutinando nuevas fuerzas, incluso no indígenas. Este paso también fortalece posturas que sin dejar de lado la reivindicación por la tierra y la exclusión, abren paso a otras luchas más clasistas y de otras vertientes de izquierda, como la lucha anti neoliberal. La lucha por la tierra se convierte en lucha por el territorio, que está ligado al concepto de nacionalidad que, a su vez, está ligado con el de interculturalidad, condición primera para lograr un Estado Plurinacional.

En el presente, los tres movimientos más fuertes: FENOCIN, FEINE y CONAIE (ECUARUNARI) se encuentran en franco debilitamiento como entidades de carácter nacional, lo que puede ser una oportunidad para el desarrollo de organizaciones locales indígenas. Tal debilitamiento también obedece al desarrollo y consolidación del gobierno actual, que los ha enfrentado en diversas ocasiones, en temas prioritarios como explotación petrolera y minera, agua, tierra, etc.

\section{La economía popular y solidaria en el Ecuador: una construc- ción social inconclusa}

En este apartado se abordarán los principales hallazgos que evidencien la forma en que la estructura actual de la institucionalidad pública, particularmente las entidades gubernamentales del sector de la economía popular y solidaria y del sector financiero popular y solida- 
rio: Instituto de Economía Popular y Solidaria (IEPS) y Corporación Nacional de Finanzas Populares y Solidarias (CONAFIPS), contribuyen al fortalecimiento de la economía social y solidaria en el Ecuador. Así como las percepciones de algunos actores de esta economía sobre la intervención del Estado a través de dichas instituciones públicas.

Siendo un estudio de carácter exploratorio y descriptivo, las preguntas metodológicas están orientadas a determinar la forma en que socialmente se construyen los nuevos sentidos, tanto en la institucionalidad pública como en los actores sociales. Las preguntas que guiarán la reflexión son: ¿la organización y estructura programática de las entidades públicas de fomento del sector de la economía social y solidaria es coherente con lo consignado en las políticas públicas?, ¿cómo se estructura el Estado para la construcción social de la economía social y solidaria?, ¿cuál es el rol y las estrategias de los actores sociales en este proceso?

El estudio constituye un esfuerzo por comprender dicho proceso desde las diversas lecturas y perspectivas que confluyen para configurar un régimen de desarrollo que garantice el "Buen Vivir" o Sumak Kawsay, y un sistema económico social y solidario en el país.

\section{Políticas para el cambio hacia un sistema económico social y solidario}

Las políticas estatales en su gran mayoría fueron aprobadas entre el 2008 y 2010, con dos Leyes: una referida a la Contratación Pública, que posibilita la implementación del programa de compras públicas inclusivas en apoyo a la economía solidaria; y la otra sobre la Soberanía Alimentaria, que fomenta especialmente la asociación de las organizaciones de economía solidaria; y con dos Códigos: De la Producción, incorpora varios artículos sobre el acceso democrático a los factores de producción y comercialización; y de Ordenamiento Territorial, que establece mecanismos para impulsar la economía solidara en los terri- 
torios. En el 2011 se aprueba la Ley de Economía Popular y Solidaria y en el 2012 su reglamento, leyes y códigos claves para la configuración de la estructura de la economía popular y solidaria en el país. Mientras en el 2014 se pone en vigencia el Código Monetario que plantea algunos cambios respecto del control y regulación del sector.

Las políticas de gobierno, del 2011 y 2012, después de la promulgación de la LOEPS, entra en vigencia varias agendas sociales y sectoriales, esta última denominada "Agenda de la Revolución de la Economía Popular y Solidaria 2011-2013”; así también, particularmente en los periodos comprendidos entre el 2008-2009 y el 20112012 , se crean y reestructuran instituciones para la regulación, control, ejecución, promoción y fomento del sector. ${ }^{32}$

A continuación se describen algunos de los elementos distintivos de la Constitución del Ecuador, el Plan Nacional del Buen Vivir y la Agenda Política Económica para el Buen Vivir. Herramientas de orden político, jurídico y técnico, que enmarcan la organización de la nueva institucionalidad del sector económico popular y solidario.

Posiblemente la característica más reveladora, de la Constitución de la República del Ecuador del 2008, es su declaración explícita de la construcción de una nueva sociedad anclada en los principios del Sumak Kawsay (SK), con un enfoque de derechos ${ }^{33}$ y garantías, en un marco constitucional democrático, plurinacional e intercultural.

32 En los anexos 1, 2,3 y 4 se detalla la relación de otras leyes o códigos con la economía popular y solidaria.

33 Para ejemplificar lo indicado, la Constitución observa siete derechos, que se relacionan con: el buen vivir; las personas y grupos de atención prioritaria; las comunidades, pueblos y nacionalidades; participación; libertad; la naturaleza (Constitución, 2008). 


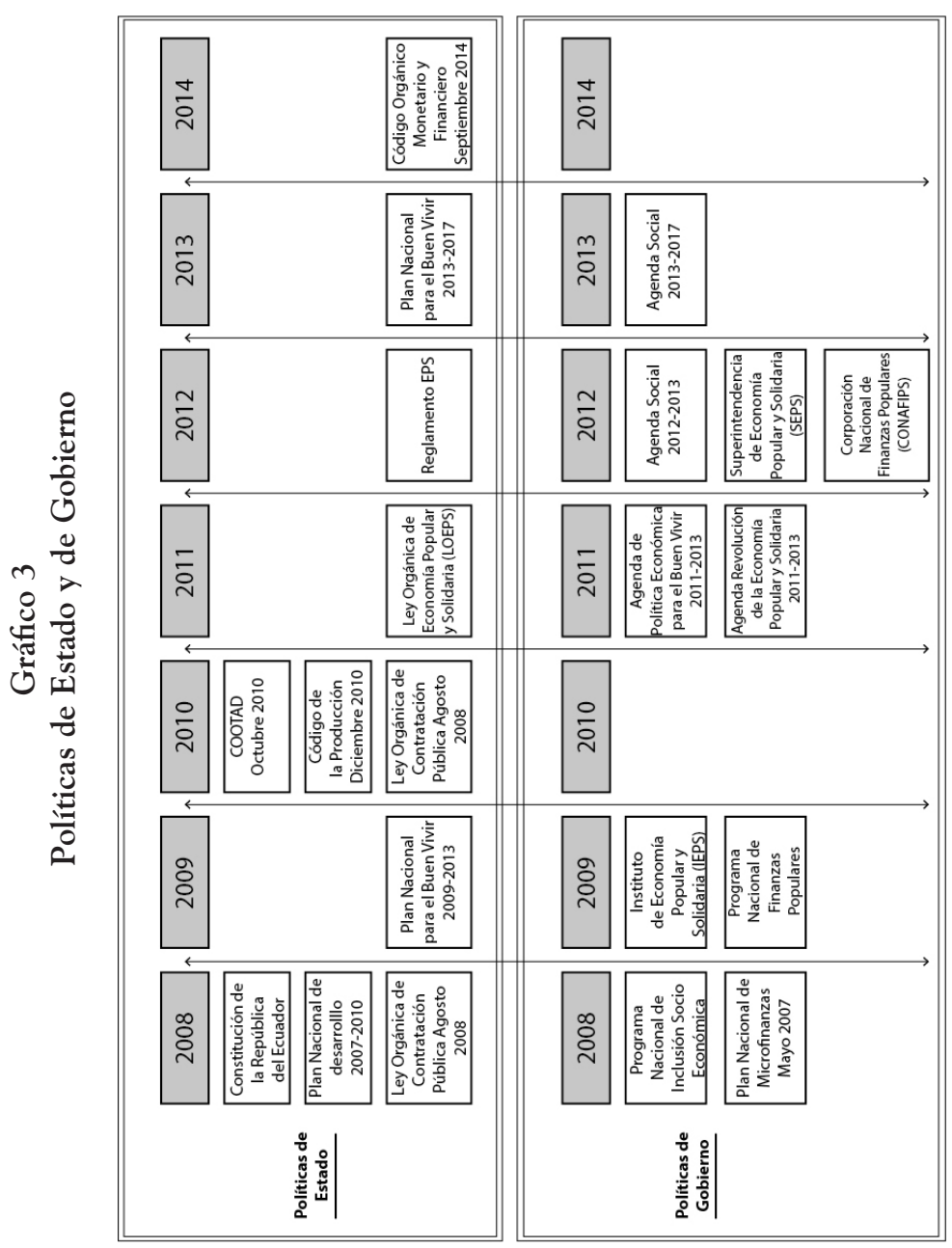

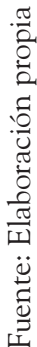


Otra característica a ser considerada es la "conjunción de unos sistemas de equidad e inclusión social" 34 que se sustentan en la conservación y protección de la naturaleza, de lo que se puede colegir que el sistema económico necesariamente deberá proteger esa relación armónica y equilibrada con la naturaleza.

También es posible inferir que se avanza a una visión integral del desarrollo, dado que incorpora los sistemas económicos, políticos, sociales, culturales y ambientales, todos estos al servicio del SK, con el propósito de mejorar la calidad de vida, con énfasis en el fortalecimiento de las capacidades; así como la consolidación de un sistema económico justo, solidario y sostenible, y la declaración de derechos a la naturaleza.

El reconocimiento del sistema económico de carácter social y solidario es otro aspecto de trascendencia, abandonando la primacía del mercado, tal definición se articula coherentemente con la visión holística del SK. Por otra parte, se destaca la relación equilibrada del Estado, sociedad y mercado con la naturaleza. Aunque para algunos autores como Huanacuni, el reconocimiento de la diversidad en las formas económicas (privada, pública, mixta, popular y solidaria) ${ }^{35}$ no es suficiente, desde la lectura del SK se requiere que las prácticas sociales sustituyan la acumulación individual, esta última debe estar subordinada al interés comunitario (Huanacuni, 2010).

Al 2014 son tres los Planes Nacionales del Buen Vivir (PNBV) establecidos en el Ecuador: el primero, Plan Nacional de Desarrollo

34 Expresión que alude al equilibrio de las sociedades al reconocer los derechos de la naturaleza, que promueve su conservación y protección. Desde esta perspectiva el régimen de desarrollo (sistemas: económico, social, político, cultura y ambiental) está al servicio del régimen del SK. (Ramírez, 2014)

35 En el Capítulo Cuarto de la Constitución, Art.283: señala que el sistema económico es social y solidario, ubicando al ser humano como centro y fin. Las formas económicas son: pública, privada, mixta, popular y solidaria (...). 
2007-2010 (al inicio de Gobierno del Presidente Rafael Correa); posteriormente se elabora el Plan Nacional para el Buen Vivir 2009-2013 (después de la aprobación de la Constitución de 2008); y el Plan para el Buen Vivir 2013-2017 (nuevo plan para el periodo siguiente). Para fines del presente estudio, se analizará en forma paralela el tratamiento de los dos últimos planes respecto al sistema económico social y solidario.

Los PNBV 2009-2013/2013-2017, mencionan como elementos centrales la puesta en marcha de varias estrategias económicas: 1) Incluyente, incorpora a los sectores excluidos del sistema capitalista, así como las formas de producción con principios de igualdad y equidad. 2) Sostenible, considera la biodiversidad y los derechos de la naturaleza. 3) Democrática, vinculada a la actoría social y participación ciudadana (SENPLADES, 2009).

Establece, entre otros aspectos:

- Pasar de una estrategia primario-exportadora a una "estrategia endógena de acumulación”, economía diversificada.

- El modo de producción se centra en el trabajo y no en la propiedad estatal.

- Construcción de una sociedad del bioconocimiento y de servicios eco-turísticos.

- La construcción de una economía popular y solidaria, como una de las herramientas para la redistribución de la riqueza (SENPLADES, 2009).

Los resultados están en función de la nueva matriz productiva; para tal efecto se determina una trayectoria de las prioridades y políticas. Los resultados esperados, son: economía diversificada, generación de mayor valor agregado e incorporación; entre algunas de las prioridades, están: nuevos patrones de consumo responsable, desarrollo de una industria dinámica y ecoeficiente, soberanía energética, etc.; las políticas previstas son: Sustitución selectiva de impor- 
taciones, inversión pública para la competitividad sistémica, gestión de recursos financieros y no financieros (SENPLADES, 2009).

En ambos planes se plantean doce objetivos macro nacionales, los cuales abordan los ámbitos: político, ambiental, social y económico. Al analizarlos en su conjunto, estos objetivos aluden al bienestar humano, al reconocimiento de la naturaleza como sujeto de derechos, a la consolidación de la participación ciudadana y democrática, al fortalecimiento de la identidad y diversidad cultural, aspectos que, se según se señala en el Plan, claramente se sustentan en una "estrategia endógena para la satisfacción de necesidades” (SENPLADES, 2009).

En el Plan del periodo 2011-2013, el objetivo 11 refiere el establecimiento de un sistema Económico, Social, Solidario y Sostenible; mientras que el Plan del 2013-2017, el objetivo ocho indica la consolidación del sistema económico social y solidario, de forma sostenible. $\mathrm{Al}$ analizar los objetivos mencionados, posiblemente cabe preguntarse: ¿de qué manera el Estado está concibiendo la economía social y solidaria?, ¿cómo debería ser la transición de una economía de mercado a una economía solidaria?, ¿qué peso debería tener la economía popular y solidaria en el sistema económico social y solidario?, ¿realmente son oportunas las políticas planteadas en el plan, frente a la realidad territorial?; todas estas constituyen inquietudes que, si bien no intentan ser dilucidas en este estudio, acarrean numerosas reflexiones.

Según Ramírez, las respuestas pueden ser multidimensionales, para este autor el PNBV, asume "que el plano económico del SK equivale a la economía social, sostenible y solidaria, que a su vez implica una economía endógena, sostenible y territorialmente equilibrada" (Ramírez, 2014). En todo caso, dado que los cambios son estructurales, será necesario esperar y valorar en el mediano y largo plazos, si la implementación de las políticas relacionadas con el sistema económico social y solidario, y con el sector de la economía popular y solidaria, fueron las correctas. 
Otra herramienta es la Agenda Económica para el Buen Vivir 2011-2013 que se constituye en uno de los ejes de consolidación de un sistema económico social y solidario, que tiene como propósito elevar el nivel de vida de todos los habitantes. Las acciones de la política económica procuran equidad social, de género, etnia, intergeneracional y regional. Este esfuerzo, según se señala en la Agenda, incorpora principalmente a los más pobres, evitando el clientelismo y convirtiendo a la política económica en parte consustancial de una estrategia alternativa (Ministerio de Coordinación de la Política Económica , 2011).

Esta nueva economía consolida el patrimonio nacional sobre los recursos estratégicos y sobre los bienes públicos, pero al mismo tiempo establece una dinámica de uso y aprovechamiento de los recursos desde una óptica sustentable, que acepta la necesidad de disponer de mecanismos de regulación y control ciudadano en la prestación de los servicios públicos. Asimismo, busca ampliar la base de productores y propietarios en un esquema que articule activa y equitativamente a todos los segmentos productivos (Ministerio de Coordinación de la Política Económica, 2011).

La Agenda es una herramienta para una gestión económica integral y articulada al interior del sector y como apoyo a los sectores de la producción, el desarrollo social y el comercio exterior. A través de lineamientos claros, ejecutables y medibles en el tiempo En tal sentido, las políticas fiscal, financiera, externa y del sector real se complementan para coadyuvar a la consecución del objetivo común de constituir un sistema económico social y solidario para el país (Ministerio de Coordinación de la Política Económica , 2011).

Para la instrumentalización del mandato establecido en la Constitución del 2008, ${ }^{36}$ se promulga la Ley Orgánica de Econo-

36 La Constitución del 2008, señala que el sistema económico es social y solidario y se integra por las formas de organización económica pública, privada, mixta, popular y solidaria. 
mía Popular y Solidaria en el 2011, ${ }^{37}$ mientras que el reglamento se aprueba en el 2012. La LOEPS, define a la economía popular y solidaria como una forma de organización económica, en donde se desarrollan procesos de producción, intercambio, comercialización, financiamiento y consumo de bienes y servicios, con el fin de satisfacer necesidades y generar ingresos. Sus integrantes pueden participar individual o colectivamente, siempre que dichas actividades se basen en relaciones de solidaridad, cooperación y reciprocidad, se privilegia al trabajo y al ser humano y respecto del sistema económico social y solidario, se orienta al buen vivir, en armonía con la naturaleza.

Las instituciones que conforman el sector de la economía popular y solidaria, son:

\section{Gráfico 4}

Instituciones que conforman el sector de la Economía Popular Solidaria

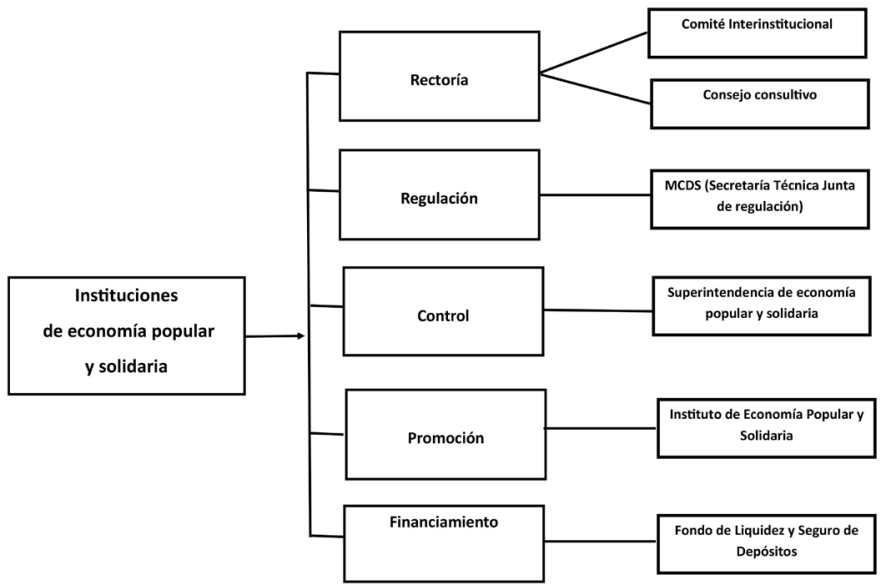

Fuente: Elaboración propia

37 La LOEPS es aprobada el 13 de abril de 2011 y publicada en RO No.444 de mayo 10 de 2011, cuyo propósito es dar un tratamiento diferenciado y preferencial del Estado con los actores de la economía popular y solidaria. 


\section{Entidades de fomento y política pública}

Si bien existe una marco institucional más amplio para la implementación de la política pública, esta parte del estudio analizará de forma exclusiva las de fomento que son responsables de su implementación a través del desarrollo de programas, proyectos y servicios en el territorio ecuatoriano; la razón fundamental de acercarse al análisis de este segmento particular, radica principalmente en la consideración de que es a través de estas organizaciones en donde se localiza la capacidad del estado ecuatoriano en evidenciar avances sociales concretos a través de la implementación de las políticas públicas en los territorios; de otro lado, en términos sociales, son estas instituciones las responsables de interactuar con los actores de la economía popular y solidaria, por lo que una vez más, el nivel de comprensión, lectura e interpretación de las realidades locales que puedan hacer, les permite, de una parte, apoyar el proceso de diseño de la política pública, y de otra, se convierten en el referente concreto para la sociedad de cómo "el quehacer" público entiende y actúa sobre el fenómeno de la EPS.

El punto de partida para abordar el tema planteado será una breve definición de las categorías utilizadas en esta parte del estudio, para sobre esta base realizar una identificación de las políticas públicas a las cuales este segmento de la institucional pública responde, para finalmente realizar un acercamiento a la gestión concreta de cada una de las instituciones. Este conjunto de elementos busca brindar luces respecto de cómo la institucionalidad pública se acerca a los actores concretos en la búsqueda de una implementación efectiva de la política pública. 


\title{
Algunas de las definiciones, son:
}

\author{
Cuadro 9 \\ Cuadro demostrativo. Principales categorías: \\ Relación entidades de fomento-política pública
}

\begin{tabular}{|c|c|}
\hline Categoría & Definición operativa \\
\hline Política pública & $\begin{array}{l}\text { “... A partir de que un tema es identificada e incorporada en la } \\
\text { agenda de discusión pública, toda toma de posición, definición } \\
\text { conceptual y posterior diseño, gestión o aplicación en curso de } \\
\text { acción a ser emprendido o adoptado por un actor en represen- } \\
\text { tación del Estado, frente a dicha cuestión, puede ser considera- } \\
\text { do como una política pública" (Ozlak, 2009). }\end{array}$ \\
\hline $\begin{array}{l}\text { Institucionalidad } \\
\text { pública }\end{array}$ & $\begin{array}{l}\text { La institucionalidad pública dentro del marco del estado de } \\
\text { derechos hace referencia al conjunto de instituciones u organis- } \\
\text { mos que conforman la estructura de gestión del estado; estas } \\
\text { instituciones están dotadas con un marco normativo y finan- } \\
\text { ciero que les permite el cumplimiento de sus competencias } \\
\text { dentro de un ámbito específico. }\end{array}$ \\
\hline Entidades de Fomento & $\begin{array}{l}\text { Esta definición se hace tomando la referencia del documento } \\
\text { "Rendición de cuentas 2013" de la Superintendencia de Econo- } \\
\text { mía Popular, figura 3. Institucionalidad de la Economía Social } \\
\text { y Solidaria, la cual establece la organización de las entidades } \\
\text { públicas. }\end{array}$ \\
\hline $\begin{array}{l}\text { Sistema Económico } \\
\text { Social y Solidaria }\end{array}$ & $\begin{array}{l}\text { El artículo } 283 \text { de la Constitución de la República del Ecuador, } \\
\text { determina que el sistema social y solidario "reconoce al ser } \\
\text { humano como sujeto y fin; propende a una relación dinámica y } \\
\text { equilibrada entre sociedad, estado y mercado, en armonía con } \\
\text { la naturaleza; y tiene como objetico garantizar la producción y } \\
\text { reproducción de las condiciones materiales e inmateriales que } \\
\text { posibiliten en buen vivir" }\end{array}$ \\
\hline $\begin{array}{l}\text { Economía Popular y } \\
\text { Solidaria }\end{array}$ & $\begin{array}{l}\text { Esta definición se inscribe en el Título I, artículolde la Ley Or- } \\
\text { gánica de Economía Popular y Solidaria y del sector Financiero } \\
\text { Popular y Solidario, y se define como la forma de organización } \\
\text { económica, donde sus integrantes, individual o colectivamente, } \\
\text { organizan y desarrollan procesos de producción, intercambio, } \\
\text { comercialización, financiamiento y consumo de bienes y servi- } \\
\text { cios, para satisfacer necesidades y generar ingresos, basados en } \\
\text { relaciones de solidaridad cooperación y reciprocidad, privile- } \\
\text { giando al trabajo y al ser humano como sujeto y fin de su ac- } \\
\text { tividad, orientada al buen vivir, en armonía con la naturaleza, } \\
\text { por sobre la apropiación, el lucro, y la acumulación del capital. }\end{array}$ \\
\hline
\end{tabular}




\begin{tabular}{|l|l|}
\hline $\begin{array}{l}\text { Actores de la Economía } \\
\text { popular y Solidaria }\end{array}$ & $\begin{array}{l}\text { Un actor social es un sujeto colectivo estructurado a partir de } \\
\text { una conciencia de identidad propia, portador de valores, po- } \\
\text { seedor de un cierto número de recursos que le permiten actuar } \\
\text { en el seno de una sociedad con vistas a defender los intereses } \\
\text { de los miembros que lo componen y/o de los individuos que } \\
\text { representa, para dar respuesta a las necesidades identificadas } \\
\text { como prioritarias. } \\
\text { También puede ser entendido como un grupo de intervención, } \\
\text { tal que percibe a sus miembros como productores de su histo- } \\
\text { ria, para la transformación de su situación. O sea que el actor } \\
\text { social actúa sobre el exterior, pero también sobre sí mismo. } \\
\text { En ambos casos, el actor se ubica como sujeto colectivo, entre } \\
\text { el individuo y el Estado. En dicho sentido es generador de } \\
\text { estrategias de acción (acciones sociales), que contribuyen a la } \\
\text { gestión y transformación de la sociedad. Touraine (1994) }\end{array}$ \\
\hline
\end{tabular}

Fuente: Varios autores

Elaboración: Autora

Las definiciones antes mencionadas ayudan a entender de mejor manera el alcance de los términos que se usarán para el proceso de descripción y análisis, por lo que el valor principal de este ejercicio debe ser visto desde un carácter pedagógico.

Como se describe en la segunda sección del libro, la estructura de la institucionalidad pública de la economía social y solidaria está organizada a través de cuatro ámbitos de gestión, a saber: rectoría, regulación, control, y fomento. Cada ámbito lo conforman un grupo de instituciones, encargadas en su conjunto de realizar intervenciones en el marco de las competencias asignadas en función de viabilizar el desarrollo de las políticas públicas, objetivos y metas. En este sentido, identificar las políticas públicas y su relación con los ámbitos de la institucionalidad nos permite contextuar y entender las actuaciones institucionales más allá del nivel de eficiencia y cumplimientos de las mismas, para acercarnos al nivel de pertinencia y coherencia en función de responder a la agenda política en el tema, misma que se puede resumir como: la construcción progresiva del sistema económico social y solidario en el Ecuador. 
La premisa básica parte de dos supuestos metodológicos: el primero da cuenta de la calidad y cantidad de políticas es suficiente para orientar la acción de la institucionalidad pública hacia los resultados esperados; mientras el segundo hace referencia a las capacidades y recursos institucionales con que cuentan las organizaciones para diseñar e implementar intervenciones socialmente necesarias y articuladas a la policía pública a la cual deben responder. Este ejercicio supone valorar los resultados institucionales más allá del cumplimiento de las herramientas de programación operativa y presupuestación que el sector público ha desarrollado para su intervención institucional; la autora se refiere a los planes anuales de la política pública, y a los planes operativos anuales.

En la misma sección también se describen las principales orientaciones estratégicas que el estado ecuatoriano ha generado en función de guiar las intervenciones de la institucionalidad pública; estas orientaciones se expresan en documentos oficiales tales como el Plan Nacional del Buen Vivir 2009-2013, y 2013-2017; La Agenda de la Política Económica para el Buen Vivir 2011-2013; La Agenda de la Revolución de la Economía popular y Solidaria 2011-2013. A raíz de estas orientaciones cada institución establece sus estructuras estratégicas y programáticas que les permitan responder y alinearse a los niveles de política del más alto nivel.

Para este ejercicio, se tomó como referencia principal la "Agenda de la Revolución de la Economía Popular y Solidaria”, ya que en ella se expresan con claridad los ejes de trabajo y sus respectivas políticas, como se demuestra a continuación: 


\section{Cuadro 10 \\ Cuadro demostrativo. Ejes de acción y políticas públicas de la Agenda de la Revolución de la Economía Popular y Solidaria}

\begin{tabular}{|c|c|}
\hline Ejes de Acción & Políticas \\
\hline $\begin{array}{l}\text { Fortalecimiento y dina- } \\
\text { mización de los entrama- } \\
\text { dos socioeconómicos de } \\
\text { la EPS }\end{array}$ & $\begin{array}{l}\text { Fortalecer el entramado alimentos } \\
\text { Fortalecer el entramado turismo } \\
\text { Fortalecer el entramado manufacturas } \\
\text { Impulsar el mejoramiento del hábitat y el desarro- } \\
\text { llo comunitario. } \\
\text { Fortalecer el entramado de servicios }\end{array}$ \\
\hline $\begin{array}{l}\text { Acceso, democratización, } \\
\text { control y propiedad de } \\
\text { los factores económicos }\end{array}$ & $\begin{array}{l}\text { Facilitar el acceso a tierra, agua, suelo, patrimonio natural, } \\
\text { espacio público, y uso de recursos productivos. } \\
\text { Fortalecer y desarrollar sistemas de asistencia técnica, ca- } \\
\text { pacitación, formación, profesionalización, e intercambio } \\
\text { de saberes. } \\
\text { Innovar y desarrollar sistemas tecnológicos de investigación y } \\
\text { conocimiento } \\
\text { Facilitar el acceso para insumos intermedios, herramientas, } \\
\text { maquinarias e infraestructura productiva } \\
\text { Facilitar el acceso a seguros de producción }\end{array}$ \\
\hline $\begin{array}{l}\text { Fortalecimiento del } \\
\text { sistema popular y solida- } \\
\text { rio articulado a la banca } \\
\text { pública y a la inversión } \\
\text { productiva }\end{array}$ & $\begin{array}{l}\text { Fortalecer y consolidar las entidades del sector financiero } \\
\text { popular y solidario. } \\
\text { Articular al sector financiero popular y solidario con la banca } \\
\text { pública a nivel territorial. } \\
\text { Dinamizar los medios de cobro y pago, para garantizar el } \\
\text { intercambio a nivel nacional e internacional. } \\
\text { Impulsar el uso de medios de pago complementarios. }\end{array}$ \\
\hline $\begin{array}{l}\text { Generación de empleo } \\
\text { digno }\end{array}$ & $\begin{array}{l}\text { Conformar y consolidar formas solidarias y asociativas de } \\
\text { empleo digno articulados a los entramados socioeconómicos } \\
\text { de la economía popular y solidaria. } \\
\text { Impulsar la remuneración de salarios dignos para los trabaja- } \\
\text { dores/as de la economía popular y solidaria. }\end{array}$ \\
\hline $\begin{array}{l}\text { Estructuración de ins- } \\
\text { titucionalidad para la } \\
\text { economía popular y } \\
\text { solidaria }\end{array}$ & $\begin{array}{l}\text { Política de fomento, promoción e incentivo. } \\
\text { Desarrollar y fortalecer la arquitectura institucional pública } \\
\text { Generar normas y regulaciones } \\
\text { Generar un sistema nacional de información }\end{array}$ \\
\hline
\end{tabular}

Fuente: MIES

Elaboración: Autora 
La implementación de estas orientaciones, en términos sociales claramente buscan fortalecer y consolidar el tejido social y la actoría ciudadana en función de promover e incentivar las expresiones de economía social y solidaria; mientras que en términos institucionales, se orientan al fortalecimiento de la acción estatal, de tal forma que genere condiciones, mecanismos e instrumentos necesarios como soporte al proceso de construcción del sector de la economía popular y solidaria.

El siguiente cuadro intenta identificar y describir la relación entre "entidades de fomento" de la economía popular y solidaria, y la política pública que definen los entes rectores del sector a través de sus instrumentos de política como son las agendas.

Cuadro 11

Cuadro demostrativo. Relación entidades de fomento

y política pública. Agenda de la Revolución

de la Economía Popular y Solidaria

\begin{tabular}{|c|c|c|}
\hline $\begin{array}{c}\text { Entidades de } \\
\text { Fomento }\end{array}$ & Ejes de Acción agenda & Política Pública agenda \\
\hline \multirow[t]{2}{*}{$\begin{array}{l}\text { Corporación Na- } \\
\text { cional de Finanzas } \\
\text { Popular y Solidarias } \\
\text { (CONAFIPS) }\end{array}$} & \multirow{2}{*}{$\begin{array}{l}\text { Fortalecimiento del sistema } \\
\text { financiero popular y soli- } \\
\text { dario articulado a la banca } \\
\text { pública y a la inversión } \\
\text { pública }\end{array}$} & $\begin{array}{l}\text { Fortalecer, consolidar y articular entre } \\
\text { sí a las organizaciones del sector fi- } \\
\text { nanciero popular y solidario (CONA- } \\
\text { FIPS 2013). }\end{array}$ \\
\hline & & $\begin{array}{l}\text { Articular al sector financiero popular } \\
\text { y solidario con la banca pública y el } \\
\text { sistema financiero nacional (CONA- } \\
\text { FIPS 2013) }\end{array}$ \\
\hline \multirow{5}{*}{$\begin{array}{l}\text { Instituto de Economía } \\
\text { Popular y Solidaria } \\
\text { (IEPS) }\end{array}$} & \multirow{5}{*}{$\begin{array}{l}\text { Fortalecimiento y dinami- } \\
\text { zación de los entramados } \\
\text { socioeconómicos de la eco- } \\
\text { nomía popular y solidaria. }\end{array}$} & Fortalecer el entramado de alimentos. \\
\hline & & Fortalecer el entramado de turismo \\
\hline & & $\begin{array}{l}\text { Fortalecer el entramado de } \\
\text { Manufacturas }\end{array}$ \\
\hline & & $\begin{array}{l}\text { Impulsar el mejoramiento de hábitat y } \\
\text { el desarrollo comunitario }\end{array}$ \\
\hline & & Fortalecer el entramado de servicios \\
\hline
\end{tabular}

Fuente: Agenda de la Revolución de la Economía Popular y solidaria 2011-2013; Informe de gestión "CONAFIPS" 2013

Elaboración: Autora 
El ejercicio de correspondencia que se muestra en el cuadro anterior obedece básicamente al criterio de la autora, tomando como base los documentos oficiales, los cuales en algunos casos evidencian ésta relación entre política pública y responsabilidad institucional; en los casos en que los documentos oficiales no permiten identificar con claridad ésta relación, se analizan las misiones institucionales, las cuales expresan la razón de ser de las organizaciones.

La identificación de las políticas públicas a las que responden las "instituciones de fomento" es un primer paso de este proceso de análisis, el cual, permite evidenciar los ámbitos de responsabilidad de las instituciones estudiadas en el contexto global de la construcción del sistema económico social y solidario en el país. En efecto, mientras que la CONAFIPS se orienta a aportar en el desarrollo y fortalecimiento de mecanismos y servicios financieros, así como en la construcción de espacios de coordinación y fortalecimiento de las organizaciones del sector financiero de la economía popular y solidaria; el IEPS se orienta al fomento de iniciativas productivas de los diversos sectores de la economía popular y solidaria, así como al posicionamiento de los productos y servicios que estas expresiones económicas desarrollan.

Descrito estos elementos es necesario profundizar en las prácticas institucionales de tal forma que podamos identificar sus actuaciones programática para poder hacer una valoración de su alineación con las políticas públicas sectoriales antes descritas, por lo que las siguientes paginas las dedicaremos a profundizar en el "quehacer" de las instituciones; debido a consideraciones metodológicas el periodo escogido para la toma de datos corresponde al año fiscal 2013. 


\section{Análisis de la intervención de las entidades de Fomento en el periodo fiscal 2014}

\section{Corporación Nacional de Finanzas Populares y Solidarias (CONAFIPS)}

\section{Marco institucional}

La CONAFIPS se crea en mayo del 2011, sobre la base de la promulgación de la "Ley orgánica de Economía Popular y Solidaria y del Sector Financiero Popular y Solidario”, esta organización en términos formales nacía, no obstante, es importante mencionar tal como lo destaca el informe del año 2013 de la misma CONAFIPS, esta asumió todos los derechos y obligaciones del hasta ese momento Programa Nacional de finanzas Populares, Emprendimientos y Economía Solidaria "PNFPEES".

Para poder aportar con la identificación de la organización, a continuación se describen algunos datos de la misma:

Base legal de creación: Artículo 158 de la Ley Orgánica de la Economía Popular y Solidaria y del Sector Financiero Popular y Solidario LOEPS, publicada en el Registro Oficial No. 444 del 10 de mayo de 2011.

Misión: Brindar servicios financieros con sujeción a la política dictada por el comité interinstitucional a las organizaciones amparadas por la LOEPS, bajo mecanismos de servicios financieros y crediticios de segundo piso; para la cual se ejercerá las funciones que constarán en su estatuto social (Presidencia de la República, 2011).

Visión: Ser líder a nivel nacional de la prestación de productos y servicios a las organizaciones del sector financiero popular y solidario, comprometidos con el desarrollo de la economía popular y solidaria, en el marco del sistema económico social y solidario. 
Objetivo: Apoyar la expansión y fortalecimiento de las organizaciones del sector financiero popular y solidario, como mecanismo de fomento al desarrollo local, orientado a potenciar las capacidades de las personas naturales y jurídicas amparadas en la ley orgánica de la economía popular y solidaria y del sector financiero popular y solidario.

Objetivos estratégicos 2014-2017: a) Fortalecer a las organizaciones del sistema económico popular y solidario. b) Diseñar, promover e implementar productos financieros de segundo piso acorde a las necesidades de la economía popular y solidaria. c) Generar y mantener productos y servicios de tecnología de información integrales para las OSFPS y la CONAFIPS. d) Posicionar a la CONAFIPS en el sistema económico social y solidario, como una organización financiera pública eficiente, que impulsa la inclusión económica y social.

Presupuesto 2014: Según el informe de formulario ejecutivo de rendición de cuentas de la CONFIPS, el presupuesto asignado para el ejercicio 2014 asciende en dólares americanos, a la suma de \$ 12021 176,01, del cual se ejecutó la suma de \$ 11561 182,04, lo que implica un nivel de ejecución presupuestaria del 94\% en el ejercicio 2014. Es importante indicar que hasta el año 2013 se recibía financiamiento del gobierno central, y que a partir de este año, los recursos se obtienen vía autofinanciamiento.

El directorio se encuentra conformado por un cuerpo colegiado de los ministerios del gobierno central que cuya accionar se encuentra relacionado con la temática de la economía popular y solidaria, a saber:

- Ministerio Coordinador de Desarrollo Social —quien lo preside.

- Ministerio Coordinador de la Política Económica.

- Ministerio Coordinador de la Producción, Empleo y Competitividad.

- Ministerio de Finanzas.

- Ministerio de Inclusión Económica y Social 


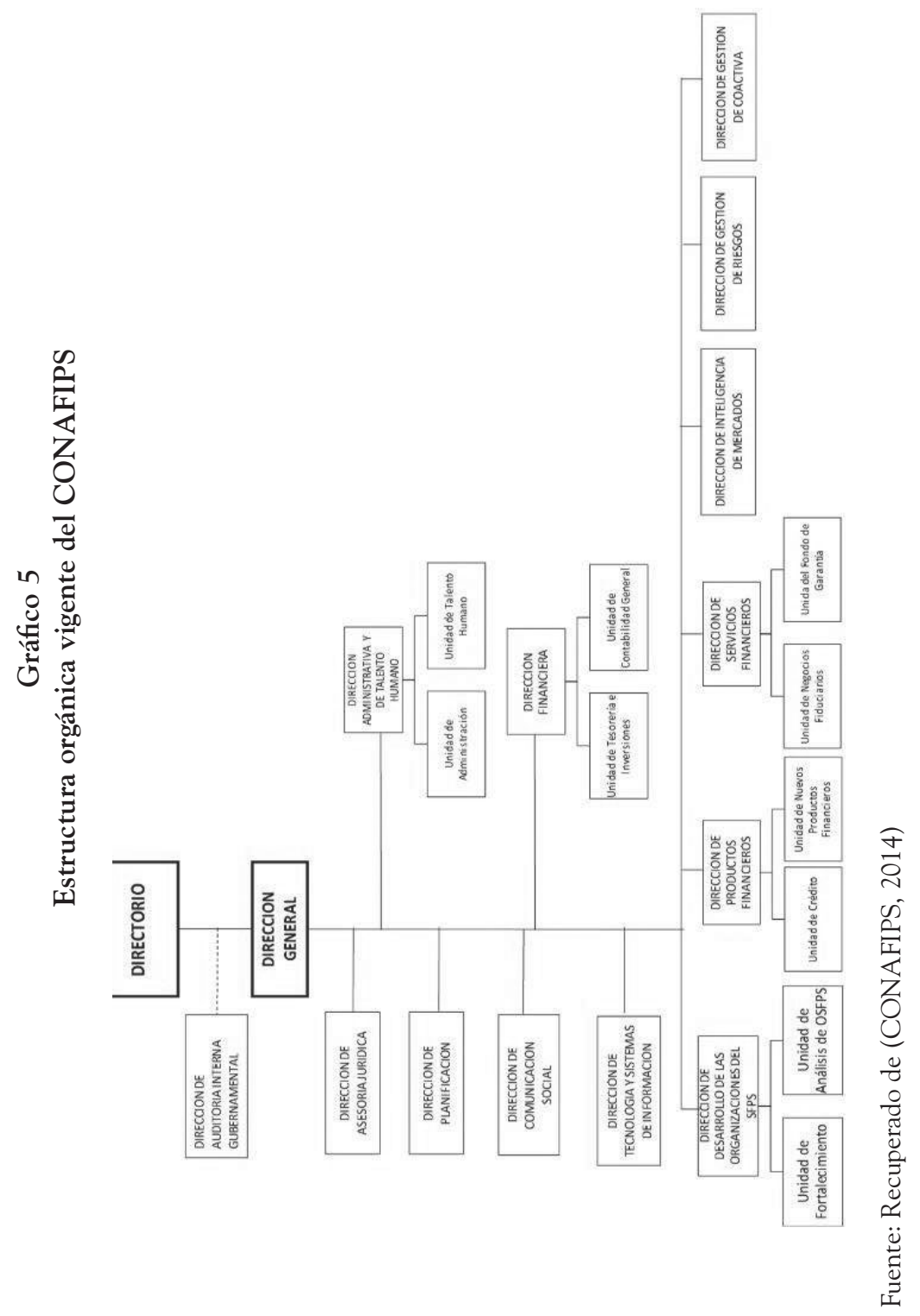


Principales intervenciones y resultados CONAFIPS

En función de sintetizar la gestión de la CONAFIPS durante el periodo 2014, se presenta el siguiente cuadro, que busca organizar la información desde los ejes de acción definidos por esta institución, hasta la identificación de resultados.

La información presentada, no refleja los detalles de las actividades, así como de los resultados institucionales del periodo, ya que como se indicó en las páginas anteriores, no se pretende valorar el accionar de la organización en función de sus resultados, sino más bien identificar el grado de alineación y contribución a la concreción de la política pública.

Cuadro 12

Cuadro demostrativo. Principales acciones y resultados CONAFIPS 2014

\begin{tabular}{|c|c|c|}
\hline Ejes de acción & Principales acciones & Principales resultados \\
\hline $\begin{array}{l}\text { Evaluación, análisis y } \\
\text { diagnóstico de las OSFPS }\end{array}$ & $\begin{array}{l}\text { Evaluación de desempeño de } \\
\text { nuevas OSFPS interesadas } \\
\text { en trabajar con la CONA- } \\
\text { FIPS, y actualización de las } \\
\text { evaluaciones del desempeño } \\
\text { para OSFPS que ya trabajan } \\
\text { con la CONAFIPS } \\
\text { Monitoreo y Financiamiento } \\
\text { trimestral de las OSFPS }\end{array}$ & $\begin{array}{l}145 \text { OSPFS se encuentran en } \\
\text { condiciones de acceder servi- } \\
\text { cios de la CONAFPS: } 90 \% \text { son } \\
\text { Cooperativas, } 8 \% \text { son ONG, } \\
2 \% \text { son Mutualistas }\end{array}$ \\
\hline $\begin{array}{l}\text { Fortalecimiento de las } \\
\text { OSFPS }\end{array}$ & $\begin{array}{l}\text { Capacitación } \\
\text { Asistencia técnica } \\
\text { Transferencia de tecnologías }\end{array}$ & $\begin{array}{l}550 \text { OSFPS participaron en } \\
\text { procesos de capacitación, } \\
\text { asistencia técnica y/o transfe- } \\
\text { rencia de tecnologías }\end{array}$ \\
\hline
\end{tabular}




\begin{tabular}{|c|c|c|}
\hline \multirow[t]{3}{*}{$\begin{array}{l}\text { Productos financieros } \\
\text { para las OSFPS }\end{array}$} & \multirow[t]{3}{*}{$\begin{array}{l}\text { Desarrollo y promoción de } \\
\text { productos financieros } \\
\text { Gestión de productos } \\
\text { financieros }\end{array}$} & $\begin{array}{l}3 \text { nuevos productos diseñados } \\
\text { en el marco del objetivo } 8 \text { del } \\
\text { PNBV } \\
\text { 1.- Reactivación de café y } \\
\text { cacao } \\
\text { 2.- Línea de financiamiento } \\
\text { para migrantes en retorno } \\
\text { 3.- Línea de financiamiento } \\
\text { "organizaciones de la EPS" } \\
\text { (con énfasis en la ruralidad) }\end{array}$ \\
\hline & & $\begin{array}{l}\text { Rediseño de la línea de finan- } \\
\text { ciamiento "vivienda de interés } \\
\text { social" }\end{array}$ \\
\hline & & $\begin{array}{l}\text { Colocado } \$ 156525602,22 \text {, a } \\
\text { través de } 75877 \text { operaciones }\end{array}$ \\
\hline \multirow[t]{2}{*}{$\begin{array}{l}\text { Servicios financieros para } \\
\text { las OSFPS }\end{array}$} & \multirow[t]{2}{*}{$\begin{array}{l}\text { Administración del fondo de } \\
\text { garantía para la EPS } \\
\text { Administración de Fondos } \\
\text { de terceros }\end{array}$} & $\begin{array}{l}\text { Generar una cartera de cré- } \\
\text { dito a favor de los emprende- } \\
\text { dores de } \$ 1247484,15 \text {, con } \\
\text { un monto garantizado de } \$ \\
801794,49\end{array}$ \\
\hline & & $\begin{array}{l}\text { Se administró } 6 \text { fondos de ter- } \\
\text { ceros, ejecutándose un monto } \\
\text { de } \$ 19531396,48\end{array}$ \\
\hline
\end{tabular}

Fuente: Rendición de cuentas CONAFIPS 2014

Elaboración: Autora

Adicionalmente, la CONAFIPS ha desarrollado una serie de instrumentos de gestión que le permite orientar su acción hacia los instrumentos de políticas a los que se adscribe; si bien es cierto hasta el año 2013 el punto de referencia de política pública estaba definido, en un nivel sectorial, por la Agenda de la Revolución de la Economía Popular y Solidaria, al terminar el plazo de vigencia de la agenda y al no ser reformulada, la CONAFIPS, realizó un ejercicio de articular y encontrar conexiones de sentido de sus acciones en el PNBV.

Si bien es cierto el cuadro anterior permite establecer una idea general de las principales acciones y resultados instituciones durante el periodo 2014, no es menos cierto que este no recoge todas las par- 
ticularidades de cada grupo de las intervenciones. Para el análisis se profundizará en la menos 2 de los 4 ejes de acción que reflejan con claridad la tendencia de la intervención institucional; nos referimos a la colocación de crédito, y al fortalecimiento de las OSFPS.

En el caso de la colocación de créditos se puede observar en el tiempo, como la tendencia ha sido creciente, seguramente entre otros factores debido al proceso a su posicionamiento y madurez en el contexto de las organizaciones financieras de la economía popular y solidaria. Los cuadros siguientes muestran los datos consolidados desde el año 2008.

Cuadro 13

Cuadro demostrativo. Evolución en la colocación del crédito CONAFIPS

\begin{tabular}{|l|l|l|}
\hline \multicolumn{2}{|c|}{ Año Cartera Operaciones } \\
\hline 2008 & $\$ 24715036,42$ & 71850 \\
\hline 2009 & $\$ 30854280,46$ & 61660 \\
\hline 2010 & $\$ 71454439,76$ & 78821 \\
\hline 2011 & $\$ 71413870,08$ & 49346 \\
\hline 2012 & $\$ 159323841,79$ & 144817 \\
\hline 2013 & $\$ 196330570,74$ & 137444 \\
\hline 2014 & $\$ 156525602,22$ & 75877 \\
\hline Total & $\$ 710617641,47$ & 619815 \\
\hline
\end{tabular}

Fuente: Rendición de cuentas CONAFIPS 2014 Elaboración: CONAFIPS 


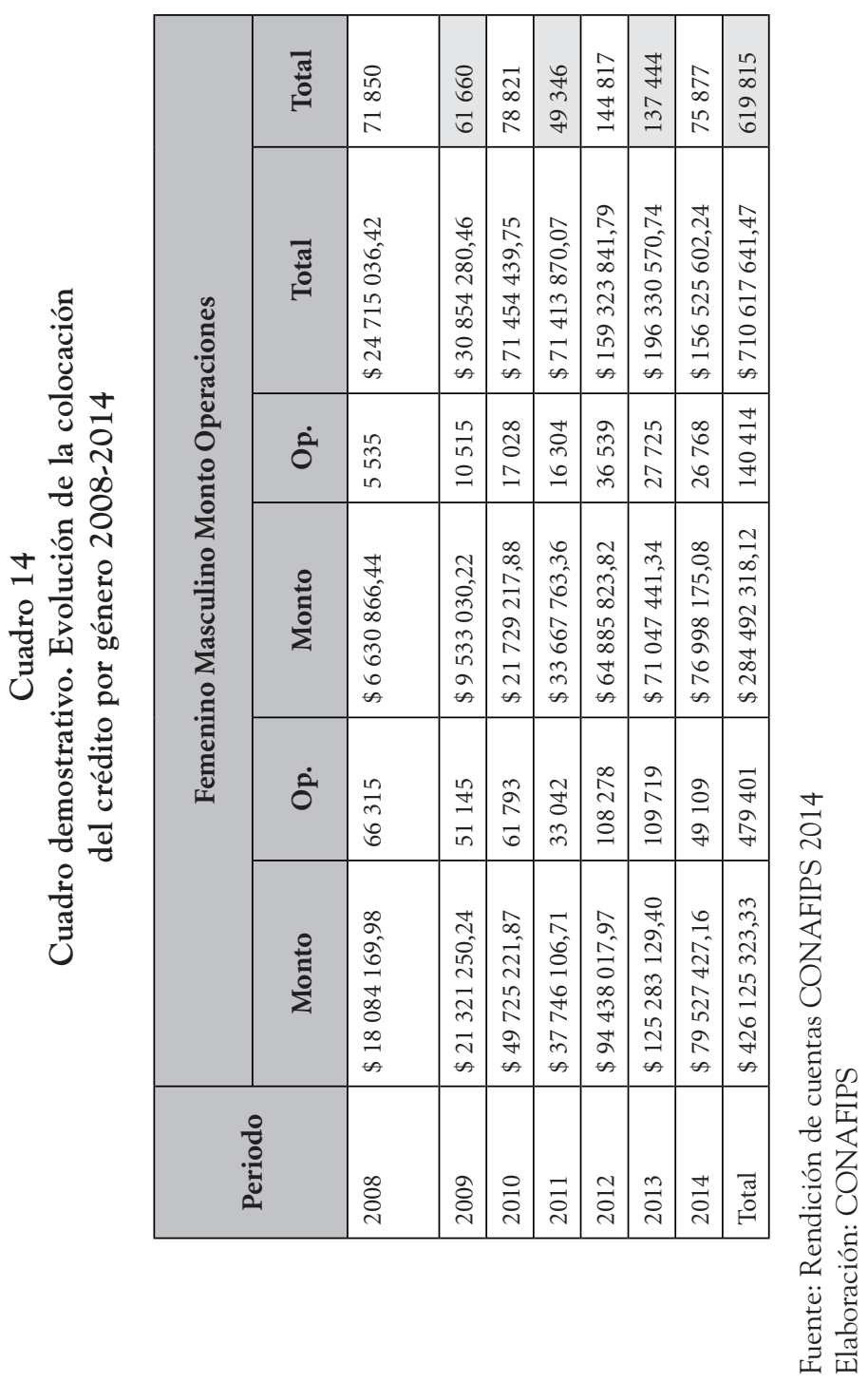




\section{Gráfico 6}

Monto colocado por género 2008-2014

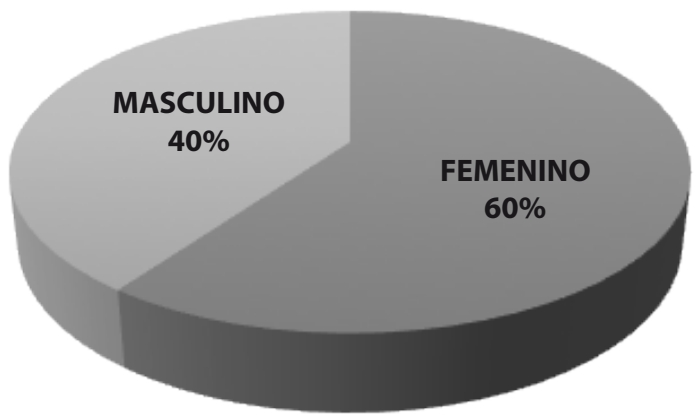

Fuente: Rendición de cuentas CONAFIPS 2014

Elaboración: CONAFIPS

\section{Gráfico 7}

Monto colocado por género 2011-2014

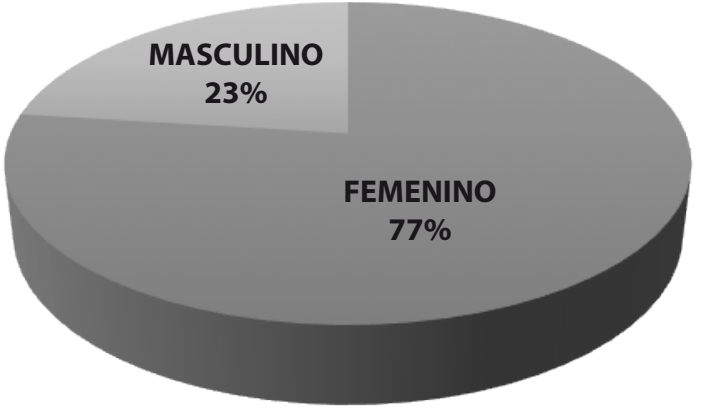

Fuente: Rendición de cuentas CONAFIPS 2014 Elaboración: CONAFIPS

A partir del año 2008, con la aprobación de la política de incentivos para la colocación de recursos en territorios con alta incidencia de pobreza por parte del Directorio del entonces Programa Sistema Nacional de Microfinanzas, el $81 \%$ de la colocación ha sido 
destinada en parroquias con un nivel de pobreza superior al $65 \%$. (CONAFIPS, 2014)

Cuadro 15

Cuadro demostrativo. Colocación del crédito por nivel de pobreza $2008-2014$

\begin{tabular}{|l|l|l|l|l|}
\hline \multicolumn{1}{|c|}{$\begin{array}{c}\text { Nivel de pobreza } \\
\text { parroquial }\end{array}$} & \multicolumn{1}{|c|}{ Monto } & \multicolumn{1}{c|}{$\%$} & \multicolumn{1}{c|}{ Operaciones } & \multicolumn{1}{c|}{$\%$} \\
\hline Zona A - Mayor al 65\% & $\$ 575779898,33$ & $81,03 \%$ & 562598 & $90,77 \%$ \\
\hline $\begin{array}{l}\text { Zona B - Entre el 38 y } \\
\text { el 65\% }\end{array}$ & $\$ 89935123,38$ & $12,66 \%$ & 39604 & $6,39 \%$ \\
\hline Zona C - Menor al 38\% & $\$ 44902619,76$ & $6,32 \%$ & 17613 & $2,84 \%$ \\
\hline Total & $\$ 710617641,47$ & $100,00 \%$ & 619815 & $100,00 \%$ \\
\hline
\end{tabular}

Fuente: Rendición de Cuentas CONAFIPS 2014

Elaboración: CONAFIPS

\section{Gráfico 8}

Operaciones por nivel de pobreza 2008-2014

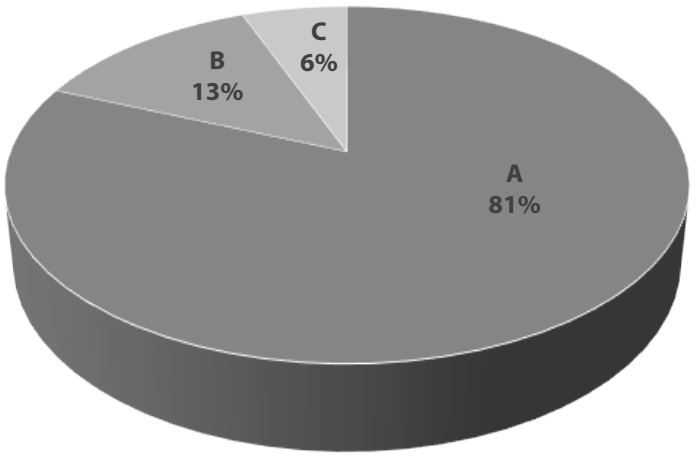

Fuente: Rendición de cuentas CONAFIPS 2014

Elaboración: CONAFIPS 


\section{Gráfico 9}

Monto colocado por nivel de pobreza 2008-2014

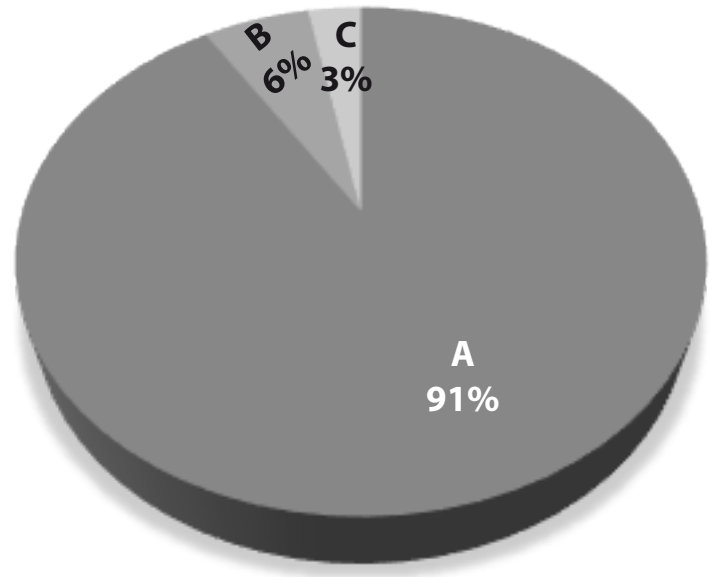

Fuente: Rendición de cuentas CONAFIPS 2014

Elaboración: CONAFIPS

En términos de fortalecimiento de las organizaciones del sector financiero popular y solidario, se puede apreciar una tendencia creciente de organizaciones que han participado en los procesos de fortalecimiento; para el 2014 participaron en estos procesos 550 organizaciones, y alrededor de 6065 personas capacitadas en temáticas relacionadas con el fortalecimiento de las OSFPS, tal como se demuestra en el siguiente cuadro:

Cuadro 16

Cuadro demostrativo. Evolución de la participación de organizaciones y personas en los procesos de fortalecimiento de las OSFPS 2008-2014

\begin{tabular}{|c|c|c|}
\hline Años & Organizaciones participantes & Personas participantes \\
\hline 2008 & 85 & 65 \\
\hline 2009 & 134 & 518 \\
\hline 2010 & 212 & 1212 \\
\hline
\end{tabular}




\begin{tabular}{|l|l|l|}
\hline 2011 & 318 & 1804 \\
\hline 2012 & 424 & 5385 \\
\hline 2013 & 456 & 5495 \\
\hline 2014 & 550 & 6065 \\
\hline
\end{tabular}

Fuente: Informe de Gestión enero-diciembre 2014 CONAFIPS

Elaboración: Autora

\section{Instituto Nacional de Economía Popular y solidaria (IEPS)}

\section{Marco institucional}

Tal como se indica en los documentos oficiales, el "IEPS es una entidad de derecho público, adscrita al Ministerio de Inclusión Económica y Social, con patrimonio propio, e independencia técnica, administrativa y financiera, la cual se encarga de brindar apoyo a los ciudadanos que desean emprender procesos de desarrollo productivo, bajo la Ley de Economía Popular y Solidaria”; de esta manera, el IEPS se constituye en parte de la arquitectura organizacional que el estado ha desarrollado para abordar el tema de la economía popular y solidaria. Debido a sus competencias y atribuciones, el acercamiento y relación directa con la ciudadanía y las organizaciones sociales se convierte en una de las características de esta institución.

Para comprender la naturaleza de la institución, a continuación se describen algunos datos de la misma:

Base legal: El IEPS se crea mediante decreto ejecutivo $\mathrm{N}^{\circ} 1668$ del 07 de abril del 2009, suscrito por el Sr. Presidente de la República, Economista Rafael Correa Delgado, y publicado en el registro oficial N 577 del 24 de abril del mismo año.

Misión: El fomento y promoción de las personas y organizaciones sujetas a esta Ley, en el contexto del sistema económico social y solidario previsto en la Constitución de la República y consisten- 
te con el Plan Nacional de Desarrollo, con sujeción a las políticas dictadas por el Comité Interinstitucional, para lo cual ejercerá las funciones que constarán en el Reglamento a la presente Ley, según el artículo 154 de la Ley de Economía Popular y Solidaria.

Visión: Construir el Sistema Económico Social y Solidario del Ecuador con el liderazgo de los actores de la Economía Popular y Solidaria, visibilizados e incluidos en políticas públicas transformadoras, desarrollando procesos productivos basados en la solidaridad, cooperación y reciprocidad, que privilegian al trabajo y al ser humano como sujeto y fin de su actividad, orientados al buen vivir del país, en armonía con la naturaleza.

Objetivos: a) Crear capacidades para que los actores de la Economía Popular y Solidaria se consoliden como sujetos económicos-sociales-políticos que participan en el nuevo régimen del buen vivir. b) Crear las condiciones para el desarrollo de los actores de la Economía Popular y Solidaria a través de su acceso a los factores productivos y de la coordinación y articulación de políticas normas $\mathrm{y}$ acciones que impulsan y/o ejecutan las instituciones del estado, los gobiernos autónomos descentralizados, las organizaciones sociales, las universidades y la comunidad en general. c) Generar oportunidades y espacios para el fortalecimiento y dinamización de los procesos de producción, distribución, circulación, financiamiento, comercialización y consumo de bienes y servicios de los actores de la economía popular y solidaria.

Ejes estratégicos: a) Fortalecimiento de actores. b) Fomento productivo. c) Intercambio de mercados. d) Estudios e investigación.

Ejes Presupuesto 2014: El presupuesto asignado para el año de análisis, según la página electrónica del IEPS, asciende a US \$ 22715 096,37; de los cuales el 31,23\% corresponde a gasto de inversión, mientras el 68,76 corresponde a gasto corriente; del monto total asignado, a diciembre 31 del 2014 se ejecutó el 96,20\%, en términos absolutos se corresponde al 
valor de 21851 053,12. La fuente íntegra de financiamiento son recursos públicos.

Gráfico 10

Estructura orgánica del IEPS

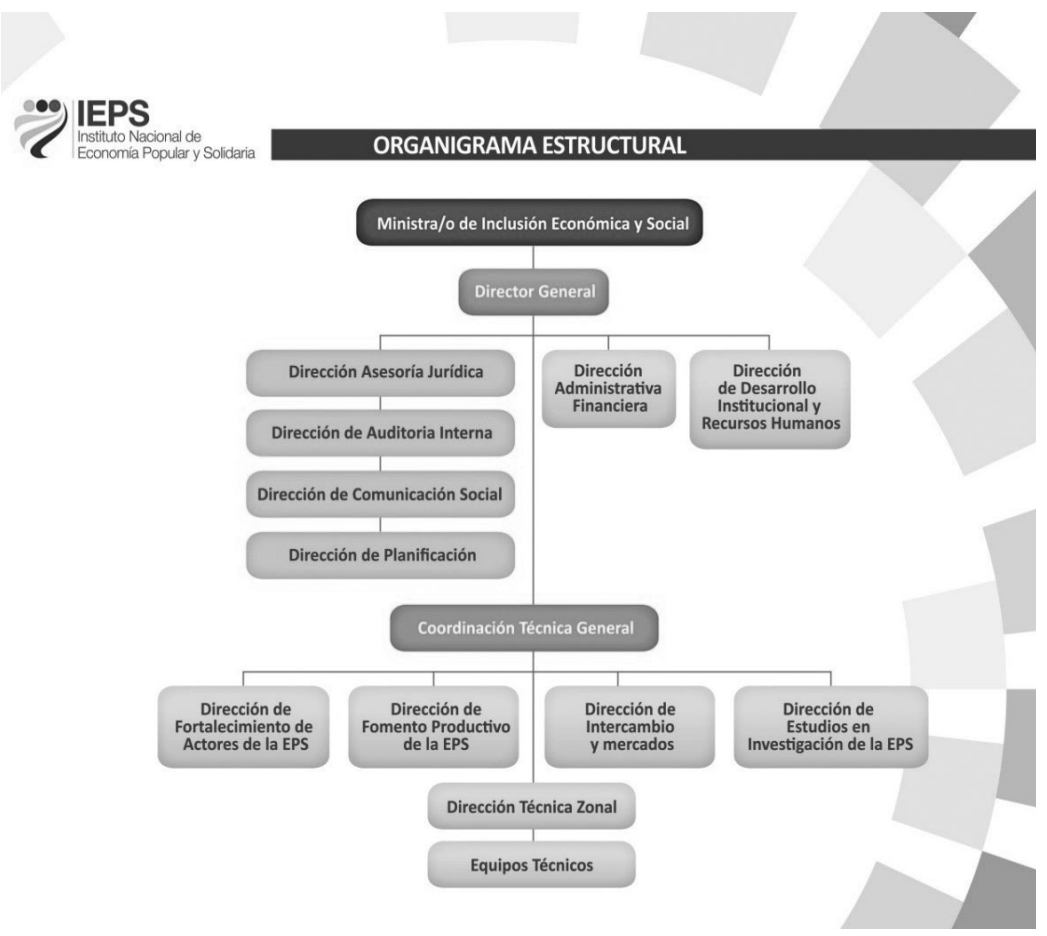

Fuente: Recuperado de (IEPS, 2013)

Principales intervenciones y resultados IEPS

En este apartado se identifican de forma sucinta las principales intervenciones institucionales, por lo que la información que se presenta, no recoge a detalle las intervenciones del IEPS durante el 
periodo 2014; no obstante, permite un marco de referencia para el análisis. El punto de partida y agregación son los ejes estratégicos. ${ }^{38}$

Cuadro 17

Cuadro demostrativo. Principales acciones y resultados IEPS 2014

\begin{tabular}{|c|c|c|}
\hline Ejes de acción & $\begin{array}{l}\text { Principales } \\
\text { acciones }\end{array}$ & Principales resultados \\
\hline \multirow[t]{4}{*}{$\begin{array}{l}\text { Fortalecimiento } \\
\text { de actores }\end{array}$} & \multirow{4}{*}{$\begin{array}{l}\text { Capacitación y } \\
\text { asistencia técnica } \\
\text { especializada } \\
\text { Diseño de un progra- } \\
\text { ma de capacitación no } \\
\text { convencional orienta- } \\
\text { do a los jóvenes }\end{array}$} & $\begin{array}{l}19216 \text { personas capacitadas para integrarse } \\
\text { a empleos directos; de estos: } 12466 \text { corres- } \\
\text { ponden a competencias asociativas, y } 6750 \text { a } \\
\text { competencias técnicas }\end{array}$ \\
\hline & & $\begin{array}{l}292 \text { emprendimientos capacitados en temas } \\
\text { administrativos }\end{array}$ \\
\hline & & $\begin{array}{l}31991 \text { personas capacitadas en educación en } \\
\text { ESS a través del programa “juventudes ess" }\end{array}$ \\
\hline & & $\begin{array}{l}496 \text { organizaciones asistida técnicamente para } \\
\text { el proceso de constitución; de estas } 166 \text { logra- } \\
\text { ron constituirse }\end{array}$ \\
\hline \multirow{4}{*}{$\begin{array}{l}\text { Fomento pro- } \\
\text { ductivo de las } \\
\text { EPS }\end{array}$} & $\begin{array}{l}\text { Impulso al acceso a } \\
\text { medios de producción }\end{array}$ & $\begin{array}{l}11000 \text { personas articuladas al cambio de la } \\
\text { matriz productiva }\end{array}$ \\
\hline & \multirow{3}{*}{$\begin{array}{l}\text { Adjudicación de } \\
\text { contratos de com- } \\
\text { pras públicas y } \\
\text { emprendimientos } \\
\text { Promoción de ini- } \\
\text { ciativas productivas } \\
\text { cofinanciadas a través } \\
\text { del crédito de desarro- } \\
\text { llo humano }\end{array}$} & $\begin{array}{l}236 \text { iniciativas productivas cofinanciadas por } \\
\text { el crédito de desarrollo humano, lo que redun- } \\
\text { dó en la generación de } 4038 \text { empleos directos }\end{array}$ \\
\hline & & $\begin{array}{l}9 \text { circuitos económicos consolidados, lo cual } \\
\text { redundó en la generación de } 2535 \text { plazas de } \\
\text { trabajo }\end{array}$ \\
\hline & & 288 emprendimientos productivos \\
\hline \multirow[t]{2}{*}{$\begin{array}{l}\text { Intercambio de } \\
\text { mercados }\end{array}$} & \multirow{2}{*}{$\begin{array}{l}\text { Generación de } 949 \\
\text { espacios de comercia- } \\
\text { lización, tales como } \\
\text { ferias inclusivas, } \\
\text { ruedas de negocios, } \\
\text { entre otros }\end{array}$} & $\begin{array}{l}\text { Incremento del } 48 \% \text { en relación con el año } \\
2013 \text { en el monto de participación de la EPS en } \\
\text { compras públicas y privadas, lo cual implica un } \\
\text { monto de USD \$ } 90414 \text { 271,88 para el año } 2014\end{array}$ \\
\hline & & $\begin{array}{l}16182 \text { personas vinculadas al mercado públi- } \\
\text { co y privado }\end{array}$ \\
\hline
\end{tabular}

38 El IEPS reportó 2467 actores a noviembre del 2014 (Anexo 6). 


\begin{tabular}{|c|c|c|}
\hline \multirow{4}{*}{$\begin{array}{l}\text { Estudios e } \\
\text { investigaciones } \\
\text { de la EPS }\end{array}$} & \multirow{4}{*}{$\begin{array}{l}\text { Estudios aplicados a } \\
\text { iniciativas guberna- } \\
\text { mentales que se están } \\
\text { implementando } \\
\text { Estudios exploratorios } \\
\text { Desarrollo de instru- } \\
\text { mentos de gestión } \\
\text { para }\end{array}$} & $\begin{array}{l}\text { Levantamiento de fichas sociodemográficas en } \\
\text { los cantones rurales de } 16 \text { provincias }\end{array}$ \\
\hline & & $\begin{array}{l}\text { Estudio de sectores y ramas de actividad } \\
\text { productiva para impulsar el desarrollo de los } \\
\text { actores de la EPS }\end{array}$ \\
\hline & & Registro automatizado de actores de la EPS \\
\hline & & $\begin{array}{l}4 \text { investigaciones desarrollados: } \\
\text { Evaluaciones de: } \\
\text { Programa de educación económica solidaria } \\
\text { Servicio de alimentación y lavandería en } \\
\text { YACHAY } \\
\text { Rueda de negocios "te vestimos Ecuador" } \\
\text { Estudios sobre: } \\
\text { Servicios de alimentación a los centros infanti- } \\
\text { les del buen vivir de Quito y Guayaquil }\end{array}$ \\
\hline
\end{tabular}

Fuente: Elaboración propia con base en el documento de rendición de cuentas IEPS 2014

\section{Relación intervenciones institucionales y política pública}

Si bien es cierto, el conjunto de las acciones desarrolladas tanto por la CONAFIPS y el IEPS durante el periodo de análisis se encuentran vinculadas con las políticas públicas descritas en páginas anteriores, los alcances de estas todavía son muy limitadas en términos de cobertura nacional; habría que preguntarse si el conjunto de acciones desarrolladas son suficientes y oportunas para alcanzar el cumplimiento de la política pública.

De otro lado, en la Agenda de la Revolución Ciudadana de la Economía Popular y Solidaria, no evidencia con claridad las metas ni los indicadores que permitan evaluar los resultados esperados en el conjunto de la implementación de la política pública, por esta razón cada institución desarrolla sus acciones en el marco de sus competencias, alineando sus acciones a las lecturas e interpretaciones de los enunciados de política. 
Ahora bien, en términos de resultados individuales, se puede mencionar que la CONAFIPS presenta desde el 2011 una tendencia de crecimiento sostenido de sus resultados, sobre todo los vinculados al fortalecimiento de las organizaciones del sector de la economía popular y solidaria, así como en la colocación de crédito de segundo nivel. A través de los documentos institucionales se puede evidenciar un crecimiento y madures en cuanto a las formas organizativas y el empleo de métodos y mecanismos de gestión; mientras que en las acciones de IEPS incorporan en una tendencia creciente a un mayor número de personas y emprendimientos en la EPS, con mejores grados de cualificación, tanto de sus proceso administrativos como de producción; en este caso se puede evidenciar una articulación de los mecanismos del estado al servicio de este sector, un ejemplo relevante se puede mencionar el acceso de los actores de la EPS al mecanismo de compras públicas.

En términos generales las acciones se alinean con sus competencias públicas, los enunciados de política de la "agenda de la revolución de la economía social y solidaria", y el "plan nacional del buen vivir", esto se expresa en la contribución a la inclusión de sectores principalmente vulnerables al acceso al crédito a través de una creciente intervención en las OSFPS tanto desde la perspectiva del apalancamiento financiero como del fortalecimiento de dichas instituciones, así como el acceso a mercados.

En términos de alcances nacionales de las intervenciones se pueden identificar algunos datos que demuestran el avance en el proceso de fortalecimiento de las expresiones económicas populares, tales como:

De los datos proporcionados por las auditorias de Deloitte \& Touche Ecuador Cía. Ltda., mayo 2014, y que constan como parte del informe de gestión de la CONAFIPS 2014, muestran resultados interesantes del proceso de acceso a servicios financieros: ... "en relación con el cumplimiento del objetivo de inclusión a personas que no tenían acceso a servicios financieros formales, teniendo en cuenta el 
concepto de fidelización, correspondió al 71\% de la muestra seleccionada" (Deloitte \& Touche Ecuador Cía. Ltda., 2014); de la misma manera el estudio de evaluación de impacto cuasi experimental T0 y T1 indica que el $61 \%$ de los emprendedores beneficiaros por la CONAFIPS ha experimentado un incremento de sus ingresos por un valor aproximado de US $\$ 117,00$. En términos de cobertura geográfica la CONAFIPS tiene cobertura en todas las provincias, en el año 2014 a través de las OSFPS fue posible contar con 638 puntos de atención.

De su parte en el caso del IEPS, la generación de alrededor de 23000 nuevos empleos, la incorporación de alrededor de 11000 personas al cambio de la matriz productiva; así como 16000 actores vinculados al mercado público y privado, constituye la más clara demostración del alineamiento de las acciones a las políticas tanto institucionales como estatales.

No obstante de los resultados indicados, el impacto socialmente hablando todavía es muy insipiente, entre otros factores por la débil articulación de las instituciones del sistema de la economía popular y solidaria, lo que hace que los resultados institucionales individuales no se capitalicen o potencien por todo el sistema.

\section{Otras entidades que se vinculan con el sector de la economía popular solidaria}

A continuación se revisan algunos ministerios que incorporan programas y mecanismos relacionados con la economía popular y solidaria:

Ministerio de Agricultura y Ganadería

El Ministerio de Agricultura y Ganadería —MAGAP — lleva adelante diversas acciones orientadas a la inclusión de actores de economía popular y solidaria y de otros propios del sector. 


\section{Cuadro 18}

\section{Programas del Ministerio de Agricultura, Ganadería, Acuacultura y Pesca}

\begin{tabular}{|c|c|c|c|}
\hline Entidad & Programa & Objetivos & Categorías \\
\hline \multirow{6}{*}{$\begin{array}{l}\text { Ministerio } \\
\text { de Agri- } \\
\text { cultura, } \\
\text { Ganadería, } \\
\text { Acuacultura } \\
\text { y Pesca }\end{array}$} & \multirow[t]{3}{*}{$\begin{array}{l}\text { Coordina- } \\
\text { ción de Redes } \\
\text { Comerciales }\end{array}$} & $\begin{array}{l}\text { Fomentar y fortalecer espacios asociativos } \\
\text { de comercialización local de redes de } \\
\text { agricultura familiar campesina }\end{array}$ & $\begin{array}{l}\text { Asesoría Técnica } \\
\text { Capacitación } \\
\text { Financiamiento }\end{array}$ \\
\hline & & $\begin{array}{l}\text { Impulsar la construcción de sistemas de } \\
\text { certificación locales asociativos que permi- } \\
\text { tan gestionar incentivos de política pública } \\
\text { para la agricultura familiar campesina }\end{array}$ & $\begin{array}{l}\text { Asesoría Técnica } \\
\text { Capacitación } \\
\text { Financiamiento }\end{array}$ \\
\hline & & $\begin{array}{l}\text { Establecer sistema de compras públicas de } \\
\text { alimentos que vincule las redes de comer- } \\
\text { cialización de la agricultura familiar cam- } \\
\text { pesina y que incentive la implementación } \\
\text { de sistemas de certificación local. }\end{array}$ & $\begin{array}{l}\text { Asesoría Técnica } \\
\text { Capacitación }\end{array}$ \\
\hline & \multirow[t]{2}{*}{$\begin{array}{l}\text { Coordi- } \\
\text { nación de } \\
\text { Innovación }\end{array}$} & $\begin{array}{l}\text { Fortalecer la institucionalidad del sector } \\
\text { público del agro, para que sea un factor } \\
\text { coadyuvante al desarrollo de la compe- } \\
\text { titividad, sostenibilidad y equidad de los } \\
\text { recursos productivos. }\end{array}$ & $\begin{array}{l}\text { Gestión de polí- } \\
\text { ticas públicas }\end{array}$ \\
\hline & & $\begin{array}{l}\text { Mejorar las condiciones de vida de los } \\
\text { agricultores y comunidades rurales } \\
\text { mediante estrategias de: inclusión social } \\
\text { de los pequeños y medianos produc- } \\
\text { tores; vinculación al mercado nacional } \\
\text { e internacional; y, de acceso a los be- } \\
\text { neficios del desarrollo de los servicios } \\
\text { e infraestructura. }\end{array}$ & $\begin{array}{l}\text { Asesoría Técnica } \\
\text { Capacitación } \\
\text { Financiamiento }\end{array}$ \\
\hline & & $\begin{array}{l}\text { Elevar la competitividad del agro, a través } \\
\text { del desarrollo productivo con un Ministe- } \\
\text { rio de Agricultura, Ganadería, Acuacultura } \\
\text { y Pesca - MAGAP, fortalecido adminis- } \\
\text { trativa y técnicamente, para alcanzar con } \\
\text { altos estándares de productividad, bajos } \\
\text { costos unitarios y calidad, que garanticen } \\
\text { la presencia estable y creciente de la pro- } \\
\text { ducción del agro en los mercados internos } \\
\text { y externos. }\end{array}$ & $\begin{array}{l}\text { Gestión de polí- } \\
\text { ticas públicas }\end{array}$ \\
\hline
\end{tabular}




\begin{tabular}{|l|l|}
\hline $\begin{array}{l}\text { Establecer un sistema de seguimiento } \\
\text { y evaluación a la gestión del agro, que } \\
\text { garantice la soberanía alimentaria y } \\
\text { su desarrollo. }\end{array}$ & $\begin{array}{l}\text { Asesoría Técnica } \\
\text { Capacitación }\end{array}$ \\
\hline $\begin{array}{l}\text { Impulsar la modernización del agro, } \\
\text { orientado a la reactivación productiva, en } \\
\text { función de la demanda y con énfasis en } \\
\text { la calidad, diferenciación y generación de } \\
\text { valor agregado orientado a su desarrollo } \\
\text { sustentable }\end{array}$ & $\begin{array}{l}\text { Asesoría Técnica } \\
\text { Financiacióniento }\end{array}$ \\
\hline $\begin{array}{l}\text { Desarrollar factores productivos, que pro- } \\
\text { porcionen condiciones humanas, natu- } \\
\text { rales y materiales en las cuales se sustente } \\
\text { la producción competitiva, a través de } \\
\text { mesas de concertación, con el enfoque de } \\
\text { cadenas agroalimentarias que consoliden } \\
\text { y modernicen al agro. }\end{array}$ & \\
\hline $\begin{array}{l}\text { Actualizar permanentemente el marco } \\
\text { jurídico institucional y sectorial de acuer- } \\
\text { do con el entorno } \\
\text { constituyan instrumentos jurín } \\
\text { aporten soluciones oportunas, dentro de } \\
\text { la perspectiva del desarrollo sustentable. }\end{array}$ & \\
\hline $\begin{array}{l}\text { Establecer mecanismos de coordinación } \\
\text { interinstitucional con Entidades Adscritas } \\
\text { y otras relacionadas con el agro, para } \\
\text { planificación, ejecución y evaluación de } \\
\text { políticas, planes, programas y proyectos } \\
\text { que permitan mejorar la prestación de } \\
\text { servicios, fortaleciendo los espacios de } \\
\text { diálogo entre el sector público y privado a } \\
\text { nivel nacional, zonal y local. }\end{array}$ & $\begin{array}{l}\text { Gestión de polí- } \\
\text { ticas públicas }\end{array}$ \\
\\
\end{tabular}

Fuente: Elaboración propia con base en datos del MAGAP, 2014

\section{Al revisar los objetivos se puede evidenciar que pueden ser organizados en cinco categorías:}

- Asesoría Técnica: Acciones que buscan fortalecer las capacidades técnicas en aspectos específicos como articulación y la asociatividad, que mejoraran la labor de los actores de economía popular y solidaria. 
- Capacitación: Acciones que generan aprendizaje colectivo en los diversos actores de economía popular y solidaria.

- Financiamiento: Acciones relacionadas con el financiamiento destinado a los diversos colectivos de economía popular y solidaria.

- Gestión de políticas públicas: Acciones de carácter interno del propio ministerio que se orientan al fortalecimiento de la entidad.

Por su parte, al definir las categorías es posible valorar de forma similar el trabajo que hacen otras entidades públicas de otros sectores del estado, a fin de identificar los puntos de cercanía entre ellas en lo referente de la economía popular y solidaria y particularmente en temas que podrían ser motivo de coordinación inter-institucional.

\section{MiNisterio de RELACIONES LABORALES}

El siguiente cuadro presenta información relacionada con el Ministerio de Relaciones Laborales, en el que se enfatiza en la acción de regulación, categoría en la que se agrupan las acciones para legalizar a las entidades de economía popular y solidaria.

\section{Ministerio DE TURISMO}

El Ministerio de Turismo orienta gran parte de sus esfuerzos a fortalecer las capacidades de los actores de economía popular y solidaria a fin de lograr que se conviertan en actores clave del turismo del país. En lo referente a las categorías antes utilizadas, añade la Promoción.

Promoción: categoría que se orienta a brindar a los actores de economía popular y solidaria, con dedicación al turismo herramientas y espacios de promoción y marketing. 


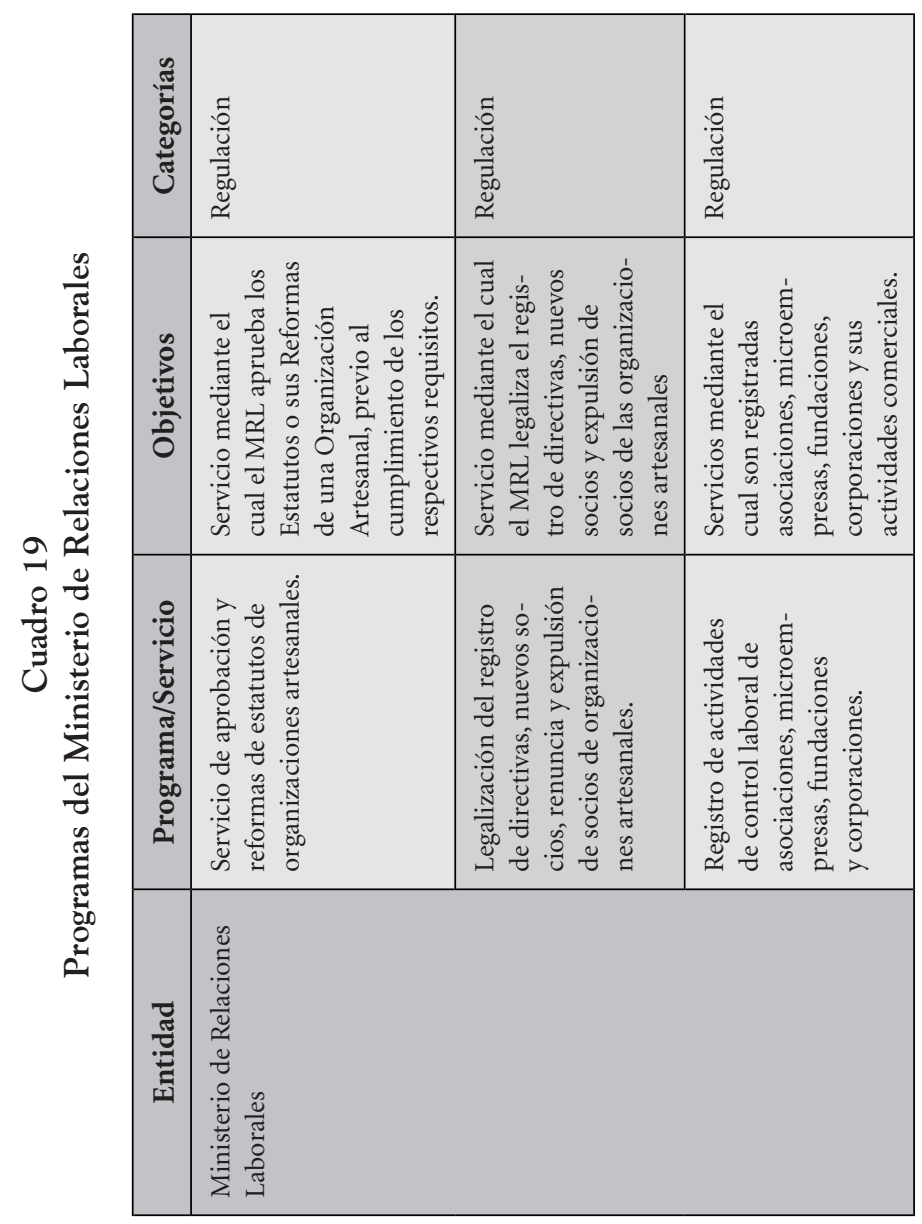

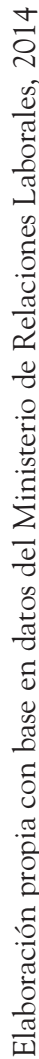

苞 
Cuadro 20

Programas del Ministerio de Turismo

\begin{tabular}{|c|c|c|c|}
\hline Entidad & Programa/Servicio & Objetivos & Categorías \\
\hline \multirow[t]{3}{*}{$\begin{array}{l}\text { Ministerio } \\
\text { de Turismo }\end{array}$} & $\begin{array}{l}\text { Programa: Consolida, } \\
\text { Turismo Comunitario }\end{array}$ & $\begin{array}{l}\text { El programa pretende me- } \\
\text { jorar el producto turístico } \\
\text { comunitario mediante el apo- } \\
\text { yo directo del Ministerio de } \\
\text { Turismo a las comunidades } \\
\text { que desarrollan actividades } \\
\text { turísticas }\end{array}$ & $\begin{array}{l}\text { Asistencia } \\
\text { técnica } \\
\text { Capacitación } \\
\text { Financiamiento } \\
\text { Promoción }\end{array}$ \\
\hline & Mi Canoa Turística & $\begin{array}{l}\text { El programa pretende favo- } \\
\text { recer el mejoramiento de la } \\
\text { calidad de vida de empren- } \\
\text { dedores de negocios micro, } \\
\text { pequeños y medianos de } \\
\text { transporte turístico maríti- } \\
\text { mo, fluvial y lacustre; a través } \\
\text { de la estructuración de una } \\
\text { oferta de calidad basada en } \\
\text { estándares técnicos y diver- } \\
\text { sificación de alternativas de } \\
\text { servicios que promuevan la } \\
\text { seguridad integral y expec- } \\
\text { tativas de turistas nacionales } \\
\text { y extranjeros. }\end{array}$ & $\begin{array}{l}\text { Asistencia } \\
\text { técnica } \\
\text { Capacitación } \\
\text { Financiamiento } \\
\text { Promoción }\end{array}$ \\
\hline & $\begin{array}{l}\text { Programa Nacional de } \\
\text { Capacitación Turística }\end{array}$ & $\begin{array}{l}\text { Fortalecer al sector turístico } \\
\text { mejorando las habilidades, } \\
\text { destrezas y conocimientos } \\
\text { técnicos del talento humano } \\
\text { para la ejecución eficiente de } \\
\text { actividades, tareas y funcio- } \\
\text { nes que realizan en el día a } \\
\text { día, mejorando los estándares } \\
\text { de calidad en la prestación de } \\
\text { servicios turísticos y de esa } \\
\text { forma generando una mayor } \\
\text { competitividad sistémica } \\
\text { del sector. }\end{array}$ & Formación \\
\hline
\end{tabular}

Fuente: Elaboración propia con base en datos del Ministerio de Turismo, 2014 


\section{Cuadro 21}

\section{Programas del Ministerio de Industrias y Productividad}

\begin{tabular}{|c|c|c|c|}
\hline Entidad & $\begin{array}{c}\text { Programa/ } \\
\text { Servicio }\end{array}$ & Objetivos & $\begin{array}{c}\text { Catego- } \\
\text { rías }\end{array}$ \\
\hline \multirow[t]{5}{*}{$\begin{array}{l}\text { Ministerio } \\
\text { de Indus- } \\
\text { trias y Pro- } \\
\text { ductividad }\end{array}$} & Exporta Fácil & $\begin{array}{l}\text { Implementar un servicio ágil, económico y } \\
\text { simplificado a través de un portal web, www. } \\
\text { exportafacil.gob.ec } \\
\text { Fomentar la inclusión de Mipymes y Artesanos } \\
\text { en los mercados internacionales, contribuyendo a } \\
\text { la competitividad de los productos ecuatorianos. }\end{array}$ & $\begin{array}{l}\text { Promoción } \\
\text { Promoción }\end{array}$ \\
\hline & & $\begin{array}{l}\text { Brindar servicios institucionales como Gobierno } \\
\text { Nacional que generen valor agregado al Exporta } \\
\text { Fácil, como capacitaciones, asistencias técnicas en } \\
\text { uso de la herramienta, en comercio exterior, en } \\
\text { búsqueda de mercados internacionales. }\end{array}$ & $\begin{array}{l}\text { Asistencia } \\
\text { técnica } \\
\text { Capacita- } \\
\text { ción }\end{array}$ \\
\hline & $\begin{array}{l}\text { Programas Con- } \\
\text { sorcios de Expor- } \\
\text { tación y origen con } \\
\text { apoyo de ONUDI }\end{array}$ & $\begin{array}{l}\text { Mejorar el desempeño económico y social a tra- } \\
\text { vés del impulso de la asociatividad en los sectores } \\
\text { productivos del país con miras a fomentar la } \\
\text { oferta exportable }\end{array}$ & $\begin{array}{l}\text { Asistencia } \\
\text { técnica } \\
\text { Capacita- } \\
\text { ción }\end{array}$ \\
\hline & Ferias Inversas & $\begin{array}{l}\text { Fomentar la sustitución estratégica de impor- } \\
\text { taciones mediante el fortalecimiento del sector } \\
\text { industrial con la oferta de las MIPYMES pro- } \\
\text { ductoras de bienes y servicios respondiendo a la } \\
\text { demanda del sector público y privado. }\end{array}$ & $\begin{array}{l}\text { Asistencia } \\
\text { técnica } \\
\text { Capacita- } \\
\text { ción }\end{array}$ \\
\hline & PRODUCEPYME & $\begin{array}{l}\text { Incrementar la productividad y competitividad de } \\
\text { las unidades productivas: empresariales, asociativas; } \\
\text { y, artesanales promoviendo la sustitución inteligente } \\
\text { de importaciones, la mejora de la productividad, } \\
\text { la generación de un mayor valor agregado y la } \\
\text { asociatividad; considerando los principios de res- } \\
\text { ponsabilidad social, de sostenibilidad ambiental y de } \\
\text { eficiencia energética, así como, la descentralización, } \\
\text { desconcentración y diversificación óptima de los } \\
\text { sectores productivos, con la gestión participativa de } \\
\text { los territorios }\end{array}$ & $\begin{array}{l}\text { Asistencia } \\
\text { técnica } \\
\text { Capacita- } \\
\text { ción }\end{array}$ \\
\hline
\end{tabular}

Fuente: Elaboración propia con base en datos del Ministerio de Industrias y Productividad, 2014 
Como se puede apreciar la gama de acciones es amplia, cada una de las entidades públicas han desarrollado respuestas diversas que permiten la inclusión de actores de economía popular y solidaria. Algunas de las actividades datan de tiempo atrás y otras se han diseñado específicamente para beneficiar al sector.

La intención de categorizarlas, a pesar de la posible arbitrariedad del recurso, es identificar áreas en las que las entidades públicas tienen experticia y podrían aportar a otras, y también identificar los puntos en común susceptibles de coordinación.

Es interesante pensar que las entidades que destinan recursos al área de la capacitación tienen la oportunidad de desarrollar contenidos que fortalezcan tanto las habilidades técnicas que los diversos colectivos de economía popular y solidaria necesitan para articularse y estar presentes en el mercado; además de lograr profundizar en los principios de una ética de economía social y solidaria, que no se centra en la acumulación de recursos económicos, sino en el bienestar de las personas. Lo que también puede ser posible en los procesos de asesoría técnica, de promoción, de mercadeo, etc. ${ }^{39}$

\section{La percepción de los actores sociales del sector de la eco- nomía popular y solidaria respecto de la intervención de las entidades públicas}

En este punto del estudio es importante reconocer la tensión natural entre las entidades públicas y los actores sociales. Ambos convergen en lo que conocemos como lo público, en debates constantes, pugnas, algunas coincidencias, que tienden a perpetuarse. Esta tensión, es propia de los sistemas democráticos. Norbert Lechner, profundiza en el concepto de lo público, como el espacio de múltiples tensiones por el control de bienes de interés, en las que convergen

39 En el anexo 5 se detalla los programas y proyectos vinculados con la economía popular y solidaria, ejecutados desde otros ministerios. 
y entran en disputa el gobierno y los actores sociales. Se establecen dicotomías: conflicto y consenso, subjetividad y formalidad, igualdad y diversidad, entre lo fáctico y lo normativo, entre deliberación y decisión, entre presente y futuro.

Es clave reconocer entonces, que lo público no es el espacio que el Estado permite u otorga a la sociedad, es un espacio que se construye en la interacción constante entre los diversos actores, en franca disputa de sentidos.

De acuerdo con la visión de Lechner (citado en Pressacco, 2008), entre las tensiones fundantes de la política, está la referente a la realidad presente y la utopía, por un lado y complementariamente, la de la institucionalidad/fáctica y el sentido que orienta los cambios (que en el caso del Ecuador, puede ser el lugar de la Constitución 2008).

Frente a tales tensiones entra en juego también la construcción de legitimidad, que de acuerdo con el mismo autor, depende de la valoración ciudadana, a tal punto que debe instalarse en el ejercicio ciudadano, la crítica. Por perfecta que sea la gestión de lo públicos por parte del Estado, los ciudadanos lo legitiman a partir de sus cuestionamientos y aportes, que de actores sociales pasan a ser actores políticos.

La imagen de la arena de batalla, en la que las ideas y las acciones entran en debate acerca de lo público es imprescindible en democracia. En el caso de este trabajo, la disputa de sentidos, se concreta en la economía social y solidaria (para los actores sociales) y la economía popular y solidaria (para las entidades de gobierno) dos facetas de una misma realidad, que se convierte en bien público.

Un trazo más a tomar en cuenta en este análisis, también de la mano de Lechner, tiene que ver con la construcción de lo público, es que en lugar del debate que surge de una ejercicio ciudadano de cuestionamiento, se da la despolitización, en la que el predominio 
consista de la política y el predominio tecnocrático, reemplazan el proceso de construcción de democracia en la que el poder en lugar de venir de abajo hacia arriba, desde la tecnocracia lo hace en sentido inverso. Al ocurrir de esta manera, se pasa por encima de los derechos a la crítica de parte de los ciudadanos y se naturaliza el orden político y social propuesto por el Estado (Pressacco, 2008).

Por otro lado, ¿qué se pierde cuando estas tensiones sobre lo público no se establecen?, siguiendo con la visión de Lechner, se afecta sobre todo y coincidentemente con el objeto de nuestro trabajo, a la solidaridad. La sociedad civil se divide, los individuos son solo eso, no ciudadanos (Pressacco, 2008).

La ruptura del componente solidario hace de la apelación al sistema político un recurso de escasa efectividad: Ello provoca la atomización y la privatización de los individuos, debilitándose los anteriores sistemas de referencia comunes y aumentando la incertidumbre acerca de lo que sería la "norma general". A falta de otros nexos de comunicación, el individuo aislado se encuentra predispuesto a aceptar la interpretación oficial de lo que está pasando (Lechner, 2006, p. 234).

Si una pérdida es el debilitamiento de lo solidario, otro aspecto a valorar, tiene que ver con la construcción del Estado, que mantiene un orden político sin espacio para otras opiniones, por ser éstas consideradas como competencia. La "naturalización" del orden existente requiere ser reforzada con la descalificación de toda posible alternativa; "se trata de impedir la construcción de alternativas (...); la autoridad es tanto más efectiva cuanto menos competencia tenga; a falta de competidor la autoridad es omnipotente" (Lechner, 2006, p. 234).

A partir de estos elementos resulta provocador analizar los aportes de los entrevistados, no sólo como una posición crítica, sino desde la comprensión de que sus opiniones son parte constituyente de la construcción de la economía social y solidaria como bien público. 
Los actores de la economía solidaria que a continuación serán citados, son organizaciones y movimientos con representación nacional, sin embargo sus criterios y reflexiones no pretenden constituir la generalidad del pensamiento a nivel de país. El interés es conocer sus percepciones en torno a la intervención de las entidades públicas, concretamente en los territorios que es donde se ejecuta la política pública a través de la implementación de programas y servicios en el sector de la economía popular y solidaria.

Las entidades son parte de una multiplicidad de actores que dan vida a la economía social y solidaria en el país. El FEPP representa a las organizaciones que llevan a cabo programas y proyectos en diversos puntos del país desde los años 70, de origen eclesial y esencialmente orientado a la ruralidad. El MESSE, que en sus documentos prefieren escribirlo en minúscula para reflejar horizontalidad, es un movimiento y como tal su fuerte está en el plano ideológico y en el planteamiento de la utopía, surge en 2007 y se fortalece en el debate Constituyente. La Coordinadora Nacional Campesina, por su parte es una organización social política que lucha por el cumplimiento pleno de los derechos de los campesinos en el Ecuador.

\section{La EPS es la economía que mueve al país}

Con la aprobación de la Constitución de 2008, se da nombre y apellido a la economía popular y solidaria, con ello también son ubicados bajo el mismo paraguas, a las cooperativas, al sector de la economía popular, a las asociaciones comunitarias, a algunos microempresarios y a los artesanos. Lo que permitiría no sólo reconocer a estos amplios sectores sino que se fundaban bases para construir un sistema económico solidario.

$\mathrm{Al}$ parecer uno de los grandes retos es lograr que todo el sector de economía popular y solidaria, sea reconocido en su real dimensión, y no sea entendida como una economía de la pobreza, que por 
ende, necesita compensaciones. Así, uno de los primeros puntos a tomar en cuenta según los criterios emitidos en la entrevista que se le realizara a José Tonello, del FEPP:

La EPS es la que tiene de pie al Ecuador, hay otra economía, pero que no le interesa ni la gran generación de empleo, ni la alimentación de los ecuatorianos/as, ni servicios humildes como pueden ser los trabajos en la construcción, o los mismos servicios domésticos, es la economía que manda, es la economía de los bancos, de las exportadoras, economía de los grandes negocios, importadores, todavía hay rezagos de la economía del latifundio, que tan fuerte ha sido en el país (J. Tonello, comunicación personal, julio de 2014).

Otro reto con el que se topa la construcción del sistema de economía social y solidaria en el país es la hegemonía del modelo económico de mercado neoliberal, que origina que las reglas del juego, en particular la normativa sea pensada de forma similar a la que se plantea para las empresas, que están insertas en el mercado. Esto se expresa también en la presencia del control de entidades de economía popular y solidaria, en grados tales que riñen con la realidad de las localidades y de las organizaciones. Es así que la igualdad que fundamenta la norma no permite interpretaciones fundadas sobre la equidad.

La motivación del control no es el ordenamiento sino la desconfianza, que puede interpretarse como desconocimiento. La distancia entre el aparato público de las organizaciones y los territorios provoca que los controles se concreten en nuevos trámites, acreditaciones, evaluaciones, etc.

Frente a este panorama marcado por la lejanía entre los conceptos y las realidades locales, es importante no perder de vista que en este momento existen mejores condiciones que antes, hay más recursos, una institucionalidad creciente y activa, legislación y normativa, en definitiva un aparato estatal vinculado con la economía popular y solidaria, incluso relacionado a diversos sectores del Estado, tanto el de inclusión social, como el de producción, el de rentas 
internas, etc. Pero, si existe esta fortaleza, ¿qué hace falta? (J. Tonello, comunicación personal, agosto 2014).

A juicio de José Tonello, la construcción de una cultura solidaria, tal construcción es tarea de todos los sectores, los estatales y los sociales. Es un proceso de largo aliento, pero que su omisión provoca los efectos que se han mencionado, lejanía entre la entidad pública de las realidades locales, reglas del juego no adecuadas para las organizaciones y territorios de economía popular y solidaria, perennización del modelo hegemónico económico, entre otros.

\section{El debate entre el la economía Social y Solidaria y la Popular, no es un asunto semántico}

Desde el MESSE, los aportes enfatizan en la dificultad de contar con espacios permanentes de debate y trabajo con el Estado, acerca de la importancia de impulsar la economía social y solidaria como prioridad, dado que ésta se relaciona con la vida, y no con la ganancia.

Su percepción es que frente a sus propuestas ha habido poca escucha de parte de las autoridades: El MESSE, participó en la construcción de la Ley de EPSS, invirtieron tiempo y recursos, y resultó que de sus aportes fueron considerados muy pocos (L. Agualongo, comunicación personal, agosto de 2014).

Es claro que el MESSE, plantea como prioritaria la distinción y la centralidad de la economía social y solidaria, como alternativa radical al libre mercado, mientras tal distinción no impulse la acción pública se sigue en el marco de un modelo hegemónico.

Al movimiento le llamó la atención, porque se hizo un seminario internacional organizado por el IEPS y por la Secretaría de Economía Popular y Solidaria; con la participación de Brasil, Chile, Uruguay, Argentina, con varias personas que aportan al pensamiento de la ES, quienes coincidieron en indicar que no es posible mezclar Economía Popular y Economía Solidaria, porque la economía 
popular tiene algunos de los principios de la Solidaria, pero funciona también dentro de lo que es el libre mercado (C. Sinchiguano, comunicación personal, agosto de 2014).

En tal escenario, la crítica del MESSE, en relación con la acción del IEPS, tiene que ver con la priorización del sector de economía popular, dado que la economía solidaria es "difusa". No obstante, las acciones implementadas se orientan a grupos de trabajadores, para incluirlos económicamente, con medidas compensatorias, sin construir o fortalecer circuitos económicos solidarios (M. Arizaga, comunicación personal, agosto de 2014).

\section{El hambre es diferente a la realidad del escritorio}

En entrevista concedida por la Coordinadora Nacional Campesina, esta pone sobre el tapete la necesidad de que los cambios sean contados a la gente con detenimiento y claridad, y fundamentalmente, desde la comprensión de que el campo, que la vida del campesino es distinta que la de los que elaboran las leyes, de los que llevan a cabo los programas, los controles, los que entregan los créditos.

Nuestra organización califica con 2 compañeras que lograron certificaciones internacionales de productos orgánicos, calificación lograda con esfuerzo que como dirigentes hemos tratado de llevar adelante a nuestra organización; dicho sea de paso, no se nos ha dado muchas atribuciones, en cuanto a ser parte de este sistema orgánico, por cuanto las tierras donde están los compañeros no están todavía legalizadas, pero sin embargo, la necesidad, el hambre es muy diferente a la realidad de un escritorio (G. Bermeo, comunicación personal, agosto de 2014).

Nuevamente, la disyuntiva de crecer y mantenerse dentro de la ley, aunque suponga contar con mayores recursos que los posibles para legalizar la situación de trabajadores o estar al día con los impuestos. No existen puntos medios, las entidades campesinas deben 
entrar en el sistema al igual que lo hacen otras entidades que no son de economía popular y solidaria.

Pero más bien tenemos una especie de queja de ciertas organizaciones sociales por cuanto la nueva modalidad de la EPS requiere o implica unas dignidades, un nuevo formato dentro de las organizaciones sociales y que eso conlleva a un pago de salarios y por ende a un consecuente pago de impuestos al SRI y demás, más bien, yo creo que está bien la forma en la que quieren manejar, con forma ordenada, pero creo que debería haber antes un esfuerzo por socializar este tipo de cambios que van a hacer, el compañero campesino se siente muchas veces aislado y cuando vienen este tipo de leyes, de cambios, se siente asustado (G. Bermeo, comunicación personal, agosto de 2014).

El cuestionamiento a la capacidad de las entidades públicas para comunicar, socializar, informar e involucrar a los actores, evidencia que los actores sociales han estado fuera de las definiciones de las acciones públicas en temas que les conciernen y que luego tampoco son comunicados y orientados para participar adecuadamente en el nuevo marco legal.

Como CNC no estamos en contra del avance de estado, para nada, más bien queremos y hacemos el llamado a que se considere a las organizaciones de campo, porque una cosa es contar la experiencia desde el escritorio y otra cosa es la experiencia desde el campo. Si ha habido organizaciones filiales de la CNC que han participado de talleres pero como organizaciones provinciales, asociaciones o corporaciones, pero decir que ha habido una invitación franca a la CNC para que sea parte de, no hemos sabido nosotros, más bien nosotros estamos involucrándonos a defender algo que ya estaba establecido, es por la misma necesidad de los compañeros que muy preocupados vienen acá, nos visitan y nos cuentan (G. Bermeo, comunicación personal, agosto de 2014). 


\section{Leyendo desde Lechner}

Los actores sociales entrevistados coinciden en la necesidad de una institucionalidad más estrechamente comprometida con la realidad de los territorios y de la gente. Dicho compromiso debería concretarse en un ajuste real de la política pública y de las acciones de las entidades públicas, a las características y demandas pertinentes del sector de la economía popular y solidaria, es decir, de las organizaciones comunitarias.

En este sentido, las entrevistas grafican aspectos mencionados por Lechner, en la construcción de lo público, los aportes y las críticas, no son otra cosa que la concreción de su rol como actores sociales y políticos, que tienen la intención de incidir en el ordenamiento social y político que se naturaliza como objetivamente necesario y riesgosamente como única vía.

Empero, para que la construcción de lo público acerca de los bienes valiosos como lo es la economía social y solidaria en el Ecuador, es imprescindible la permanencia de espacios de diálogo, debate, acción conjunta, que den forma y contenido a la intención de una alternativa real a la economía de libre mercado, tal y como se consigna en la Constitución de 2008.

\section{Conclusiones: Entre la realidad de una economía de mercado y el deseo de un sistema económico social y solidario}

El estudio busca acercarse a la institucionalidad de la economía social en el Ecuador, si bien expresa ciertos hallazgos estos no son concluyentes, dado que la realidad puede cambiar en el tiempo y porque además es posible contar con nuevos marcos teóricos interpretativos. En todo caso constituye un esfuerzo académico por comprender un "rompecabezas" que empieza a armarse con diversas visiones y definiciones. 
Entre los hallazgos más relevantes se encuentran:

- La política económica se adscribe a lo estipulado en la Constitución del 2008, y el PNBV en sus objetivos 11 y 8 , del 2011 y 2013 respectivamente, determinan los lineamientos para el sistema de la ESS y del sector de la EPS, otorgando identidad y visibilizando socialmente al sector. Sin embargo, del estudio se colige que aún persiste un enfoque de compensación social, es decir, se observa que es en el área social donde está anclada toda la institucionalidad pública y no en el área económica. ¿Por qué se quedan en el ámbito de la compensación?, la reflexión de Coraggio ofrece algunas pistas, en el sentido de que el sector de la economía popular y solidaria aún es percibida como un sector pobre, como una economía informal o de supervivencia y destinada a corregir las fallas del mercado.

- La afirmación anterior, deja pendiente una discusión o análisis, respecto de cómo efectivamente se concibe en el Ecuador la economía social y solidaria. Una corriente se adscribe a una concepción más instrumental u operativa que no aspira suprimir la economía de mercado; mientras que la economía solidaría, en algunas de sus vertientes, propone extinguir el capitalismo y no se pretende como un sector marginal, sino uno que reemplaza a la economía capitalista por una otra de carácter solidario. Empero, como sostiene Mance (2017) existe una cuestión conceptual importante en este debate, y es que en estas vertientes se plantea un tema de carácter político. Retomar la discusión en el país, es imperativo para dar viabilidad a un proyecto que requiere no sólo de una vasta discusión conceptual, sino además de una voluntad política que exprese con claridad los cambios estructurales de esta nueva institucionalidad.

- Con relación a la institucionalidad del SEPS, esta tiende a organizarse de acuerdo con lo que Morin (2010) denomi- 
na "el pensamiento en piezas sueltas".40 ¿En qué sentido?, si usamos la analogía del alfabeto, las letras por sí solas no forman las palabras, en el caso de la estructura pública sucede algo similar, las instituciones per se no construyen la EPS. Contamos con las partes, en lo legal, institucional y financiero, pero aún esas partes no aciertan con una adecuada relación intrasectorial e interinstitucional. ${ }^{41}$ Por la esencia misma de la economía solidaria, es en la conjunción de los diversos actores, en el análisis multidimensional de la economía solidaria, en la relación dinámica Estado-actores sociales, en donde se dinamizan las relaciones. Explicación que nos permite comprender que inevitablemente tanto el Estado a través de su estructura estatal como los otros actores, deben converger en diálogos y debates que contribuyan a la construcción de otra economía.

- Se constata que actualmente el país cuenta con una arquitectura organizacional de la EPS en los ámbitos de rectoría, regulación, control, financiero, promoción y fomento, pero aún este andamiaje no actúa como un sistema por las reflexiones antes indicadas. el SEPS es una forma económica más del sistema, que en la práctica se instituye en las dinámicas del mercado capitalista, esto limita su acción; y puede interpretarse que el nivel en que se encuentra es secundario. Posiblemente se deba a que la construcción todavía es embrionaria.

40 Morin (2010) sostiene que "el pensamiento que compartimenta, recorta y aísla, permite a los especialistas y expertos ser más competentes en sus ámbitos de estudio (...), y su visión determinista, mecanicista, cuantitativa y formalista ignora, oculta o disuelve todo lo que es subjetivo, afectivo, libre, creador. Además, las mentes parceladas y tecno-burocratizadas están ciegas ante las inter-retroacciones (...), todavía consideran los fenómenos según la causalidad lineal".

41 Una explicación amplia y detallada, se encuentra en E. Morin (2010). 
- Con relación al rol de las entidades públicas, estas deben ser valoradas de forma indistinta: la acción e incidencia del Comité Interinstitucional de EPS como rector de la política pública se ha caracterizado por una gestión con énfasis en el control hacia las instituciones y no hacia el sistema; la SEPS se ha esforzado por establecer un catastro del SEPS, sin embargo su relación con las organizaciones sociales ha sido matizada por una débil comprensión de las realidades, dinámicas y contextos en que se desarrollan; el IEPS en su rol de promoción y fomento, a pesar de las iniciativas y de una gestión técnica que intenta salir de un enfoque de asistencia social, todavía no logra apalancar acciones más cercanas a los actores y a los territorios; la CONAFIPS, es una de las pocas instituciones que evidencia un esfuerzo intelectual por estructurar sentidos distintos en su acción, busca dar cierto orden al sistema financiero de la EPS.

- Si bien existe una relación entre la institucionalidad pública y ciertos actores de la EPS, particularmente con las cooperativas. Esta relación no se construye necesariamente desde el territorio. En los territorios están presentes redes naturales, locales ya establecidas y que no siempre son reconocidas por los gobiernos seccionales y el gobierno central, así lo expresan algunos de los actores de la economía popular y solidaria.

- El FEPP y el MESSE son organizaciones clave especialmente en el desarrollo de la ruralidad en varias regiones del país. Es interesante notar como dentro de sus acciones hay paralelismo con las acciones que lleva adelante el Estado para promocionar la economía popular y solidaria. Sin embargo, desde las entidades públicas no se logra capitalizar el conocimiento y la experiencia de éstas y otras organizaciones para promover las iniciativas económicas locales. 
- Es inevitable, que en este análisis se mezclen, temas políticos y temas de desarrollo. En el caso del movimiento indígena, hablar de la CONAIE, es reconocer uno de los actores más importantes que resumen en sí la historia de reivindicaciones del movimiento indígena. Tal naturaleza puede ser propicia si se piensa en procesos de fortalecimiento de la economía popular y solidaria en el país. Es interesante descubrir puntos de encuentros entre el Estado y el Movimiento Indígena para el desarrollo de la economía popular y solidaria, lo cual supondría una mirada sobre la historia y el presente de este actor político y social que a su vez representa otras organizaciones como hemos revisado antes.

- Laville y Gaiger (2009) advierten no confundir el deseo con la realidad. Es necesario comprender que la ESS en Ecuador al igual que en otros países de Latinoamérica, está limitada por razones estructurales (referidas a la comprensión de la ESS, a la dinámica del mercado capitalista, al rol del Estado), por tanto sus potencialidades pueden ser disminuidas. En Ecuador, la realidad sugiere un contexto complejo, en el que coexisten acciones de cambio de la mano de la inversión pública y por otro lado, el continuismo de la presencia de poderes hegemónicos en todos los ámbitos del país, en particular los económicos, lo que hace que las iniciativas de economía social y solidaria, puedan no ser percibidas en su real dimensión. 